\title{
U-Pb Ages of Detrital Zircons from the Permo-Triassic Series of the Iberian Ranges: A Record of Variable Provenance during Rift Propagation
}

\author{
S. Sánchez Martínez, ${ }^{1, \star}$ R. De la Horra,${ }^{2}$ R. Arenas, ${ }^{1}$ A. Gerdes, ${ }^{3}$ A. B. Galán-Abellán, ${ }^{2}$ \\ J. López-Gómez, ${ }^{2}$ J. F. Barrenechea, ${ }^{4}$ and A. Arche ${ }^{2}$ \\ 1. Departamento de Petrología y Geoquímica e Instituto de Geociencias, Universidad Complutense de Madrid- \\ Consejo Superior de Investigaciones Científicas (UCM-CSIC), Universidad Complutense, 28040 Madrid, Spain; \\ 2. Departamento de Estratigrafía e Instituto de Geociencias, UCM-CSIC, Universidad Complutense, 28040 \\ Madrid, Spain; 3. Institut für Geowissenschaften, Goethe Universität, D-6438 Frankfurt am Main, Germany; \\ 4. Departamento de Cristalografía y Mineralogía e Instituto de Geociencias, UCM-CSIC, Universidad \\ Complutense, 28040 Madrid, Spain
}

\begin{abstract}
A B S T R A C T
The provenance of the Permo-Triassic series of the Talayuelas anticline (Iberian Ranges) have been studied using U$\mathrm{Pb}$ geochronology (laser ablation inductively coupled plasma mass spectrometry) of detrital zircons. These intracontinental siliciclastic series were formed by extensive sandy braided fluvial systems associated with ephemeral lake deposits and aeolian sediments, with paleocurrents suggesting constant NW-SE transport directions. Upper Permian reddish sandstones from the Upper Alcotas Formation (Lopingian) contain a dominant Variscan zircon population (290-360 Ma), which indicates source areas located in the axial zone of the Variscan belt, in the core of the IberoArmorican arc. However, in the Lower Triassic sandstones of the Cañizar Formation (Olenekian), the Variscan zircon population is almost completely replaced by Cadomian zircons (520-750 Ma), with important Avalonian (390-520 Ma), Mesoproterozoic (900-1750 Ma), Eburnian (1.78-2.35 Ga), and post-Eburnian and Archaean (>2.4 Ga) zircon populations. This detrital zircon content now suggests source areas located more to the NW, in the Avalonian microcontinent, although a limited supply coming from the southern part of Laurentia cannot be ruled out. Finally, in the Middle Triassic (Anisian), the source areas returned to the Variscan axial zone, since the Variscan zircon population is again highly dominant during this period. The changes detected in the source areas of the Permo-Triassic series are related to the development and propagation of the Iberian rift, one of the large extensional structures that determined the generation of the sedimentary basins and finally caused the breakup of Pangea. The methodology followed in this article is very useful to understand the generation and evolution of these intracontinental basins and also the relationships between the different rift systems generated in the North Atlantic realm during the PermoTriassic times.
\end{abstract}

Online enhancements: appendix tables.

\section{Introduction}

During Upper Permian-Early Triassic times, an exceptional period of global regression caused by the previous assembly of Pangea led to general deep erosion in most of the western European basins (Hallam and Wignall 1999; Heydari et al. 2001; Bourquin et al. 2007). This period was marked by 2011 .

Manuscript received April 29, 2011; accepted November 16,

* Author for correspondence; e-mail: s.sanchez@geo.ucm.es. very extensive unconformities and widespread siliciclastic rocks in continental sediments, generally attributed to "Buntsandstein" facies, deposited above Permian rocks. In the Central European basins, the Buntsandstein is mainly represented by large fluvial sand sheets associated with ephemeral lake deposits and aeolian sediments. A similar pattern of sedimentation is described for the Triassic deposits of the Iberian Basin (the sedimentary basin

[The Journal of Geology, 2012, volume 120, p. 135-154] (c) 2012 by The University of Chicago. All rights reserved. 0022-1376/2012/12002-0002\$15.00. DOI: $10.1086 / 663983$ 


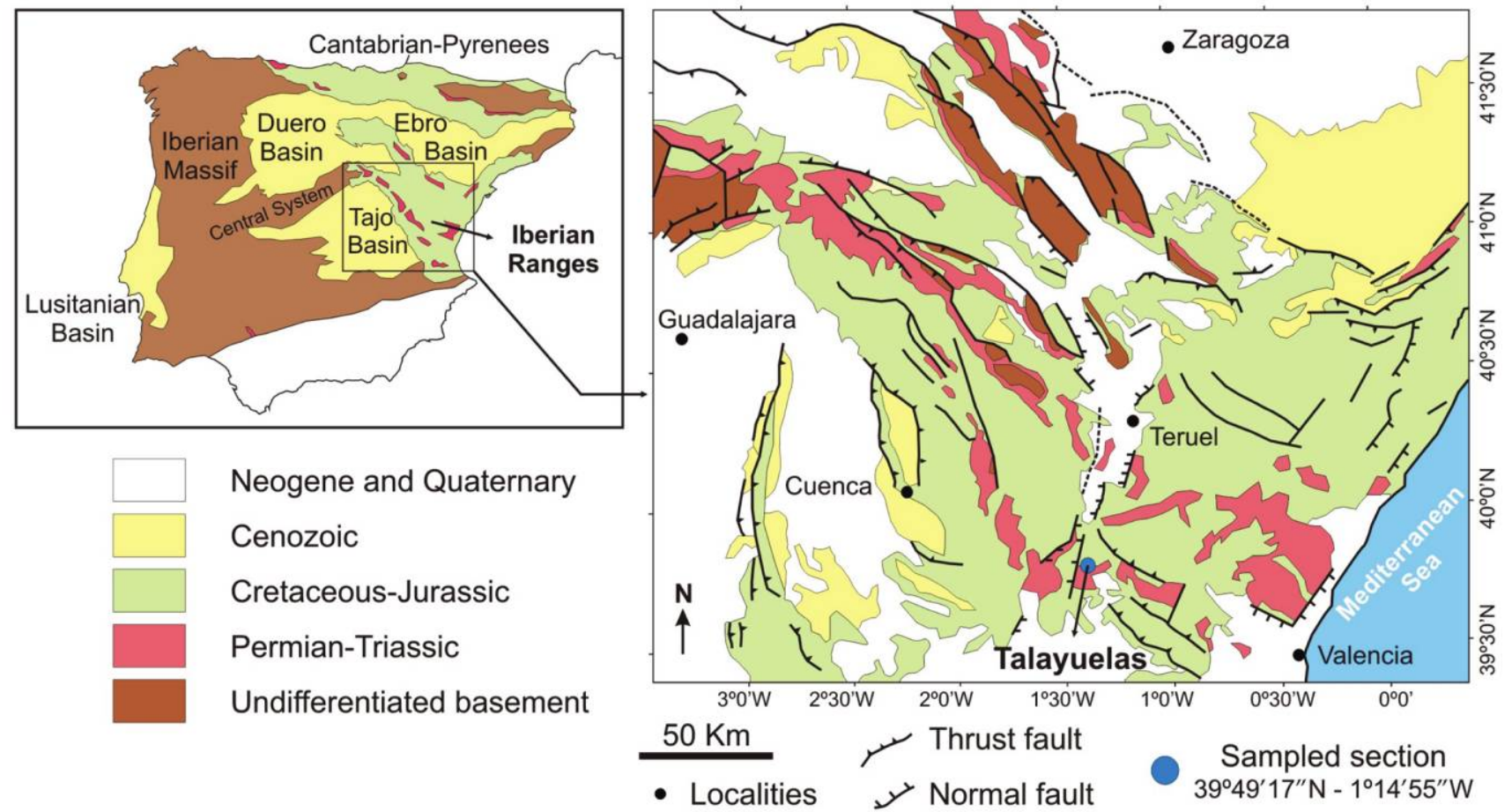

Figure 1. Simplified geological maps showing the location of the Talayuelas section in the Iberian Ranges and the general distribution of the Permo-Triassic outcrops in Iberia. The coordinates of the Permo-Triassic section where the samples for $\mathrm{U}-\mathrm{Pb}$ dating of detrital zircons were taken are also indicated.

located in the Iberian Ranges and its continuation to the NW; see figs. 1, 2), which are broadly associated with large and extensive sandy braided fluvial systems (López-Gómez et al. 2002). In all of these basins, the clear change from Permian local drainage systems to widespread systems with distant source areas marks the beginning of the Triassic sedimentation (Arche and López-Gómez 2005; Bourquin et al. 2007).

It is generally accepted that the sediment supply for the Buntsandstein sediments in the Iberian Ranges came from the axial zone of the Variscan orogen, located in northwestern areas of the Iberian Massif, although in southeastern localities, local influence of low-grade metamorphic source areas have been also proposed (Arribas et al. 1985). In the SE Iberian Basin (figs. 1, 2), local source areas could have produced some Early Triassic conglomerates, but textural features of sandstones and sedimentological evidence in the Buntsandstein are better matched with large, long, and wide rivers transporting huge amounts of detrital components (Sopeña et al. 1988; Arche and López-Gómez 2005). The important sedimentary supply during the Late Permian-Early Triassic period has been related with a stage of relief rejuvenation or an increase in precipitation (Bourquin et al. 2011). High precipitation rates could be required to produce the huge amount of clastic components typical of the Early-

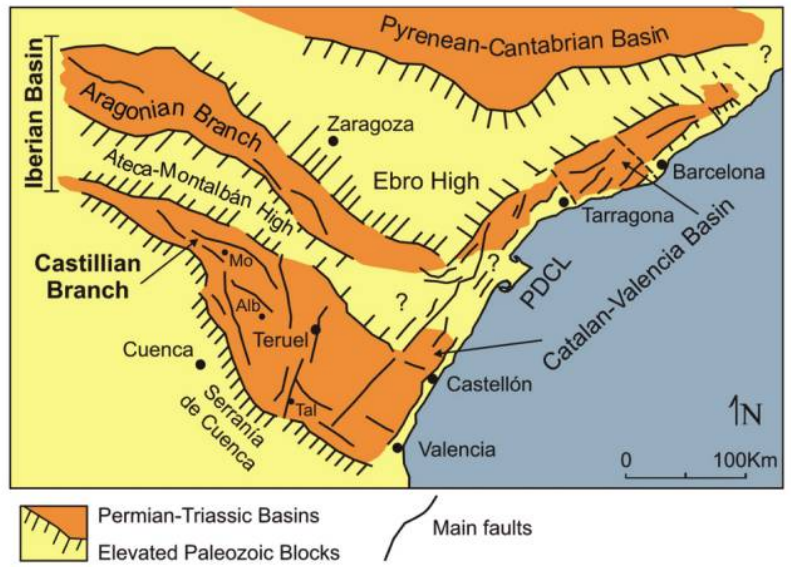

Figure 2. Reconstruction of the sedimentary basins at the base of the Triassic, showing the main Paleozoic highs, basin boundary fault systems, and related transfer faults. Tal, Talayuelas; Alb, Albarracin; Mo, Molina de Aragón; PDCL, present-day coast line. 
Middle Triassic, but it is commonly accepted that climatic conditions for most of the Middle Permian to Middle Triassic were arid to semiarid, with even a hyperarid period during the Olenekian (Durand 2008; Bourquin et al. 2011). Furthermore, wide regions on the west margin of the Tethys as well as central areas of Europe (Durand 2006; Schneider et al. 2006; Bourquin et al. 2011) and the E Iberian (Soria et al. 2011) and Catalán-Valencia basins were desertic, with aeolian influence and very low rates of precipitation.

The beginning of the Triassic sedimentation represents a key period for understanding the breakup of Pangea. However, paleogeographical data are still a matter of discussion, since there is not a clear knowledge about active sedimentary corridors and the connections between them that permitted the transport and sedimentation of the Buntsandstein series. This article explores the provenance of the Upper Permian-Early Triassic fluvial deposits in Iberia, using detrital zircon age populations. In order to achieve this objective, samples of sandstones from Upper Permian (Alcotas Formation) and Early Triassic (Cañizar Formation) series were selected. The new data show a surprising scenario for this time span, with contrasting zircon age populations providing significant information for the provenance of these sedimentary series and the evolution of the dynamic setting. The interpretation of the zircon data framed in a well-constrained reconstruction of Pangea in the area surrounding Iberia has proven to be a fruitful method for the investigation of the development of the Permo-Triassic basins and their relationships with the rift systems, which finally favored the breakup of Pangea.

\section{Geological Setting of the Permo-Triassic Series}

The extensional collapse of the Variscan Belt that started at the latest Carboniferous-Early Permian and the later westward propagation of the Neotethys during the Permian and Triassic produced a complex system of rifts in central and Western Europe (Sopeña et al. 1988; Ziegler 1988; Vargas et al. 2009). In the Iberian Plate, three main rifting systems accommodated a Permian to Mesozoic record that, after tectonic inversion, were involved in the Pyrenean-Cantabrian mountain belt, the Catalán Coastal Ranges, and the Iberian Ranges (De Vicente et al. 2009; figs. 1, 2). In the former Iberian Basin, the tectonic subsidence history is characterized by multiple pulsating periods of stretching intermitted by periods of relative tectonic quiescence and thermal subsidence that accommodated a complex record of hundreds to thousands of meters thick (Van Wees et al. 1998; Vargas et al. 2009).

The Permian-Triassic sedimentary record in the Iberian Ranges has been divided into major sedimentary sequences, each of them constituted by one or two lithological units of formation range and bounded by unconformities and/or hiatuses (Sopeña et al. 1988; López-Gómez and Arche 1993; López-Gómez et al. 2002). However, this record shows some lateral changes between the northwest and southeast areas of the Iberian Ranges as a result of a different evolution of the basin in each of those sectors. This study focuses on two continental units deposited in the SE sector of the Iberian Basin. The older one, the Alcotas Formation, is part of the upper sedimentary sequence of the Permian record, and the younger, the Cañizar Formation, represents the beginning of the first sedimentary sequence of the Triassic record in this area. The age of the Alcotas Formation is Thüringian (Middle PermianUpper Permian), while the age at the top of the Cañizar Formation is early Anisian (Doubinger et al. 1990); therefore, an Olenekian age is attributed to most of this latter unit (fig. 3). Because most of the uppermost Late Permian is eroded or probably never deposited, the Permian-Triassic transition is not recorded in the whole Iberian Basin, since it also occurs in most Western European basins (Bourquin et al. 2011). However, because rifting and subsidence were active at that time, the sedimentary record could be locally continuous across this time boundary.

In the Iberian Basin, the Permo-Triassic series were deposited in several extensional rift basins trending NW-SE with horst and graben structure. Conjugate normal faults limited the NW-SE boundaries of the basins, and associated SW-NE transfer fault systems favored the accommodation of sediments along the Iberian Basin. Extensional SW-NE systems were also developed in the eastern margin of the Iberian plate, and the Catalán-Valencia rift basin was originated during the same time interval (Vargas et al. 2009); it was filled with comparable alluvial and aeolian deposits (fig. 2).

The Alcotas Formation. The Alcotas Formation, lying unconformably on the Hercynian basement, is related to the first important phase of subsidence during the rifting evolution of the Iberian Basin, since it is the oldest Permian unit recorded in various sectors of the basin (Vargas et al. 2009). It consists of red siltstones with intercalated sandstone and sporadic conglomerate bodies that can be more than $100 \mathrm{~m}$ long and $6 \mathrm{~m}$ high. Total thickness of the formation varies from 82 to $168 \mathrm{~m}$. On the basis of sedimentary, mineralogical, and petrographic 


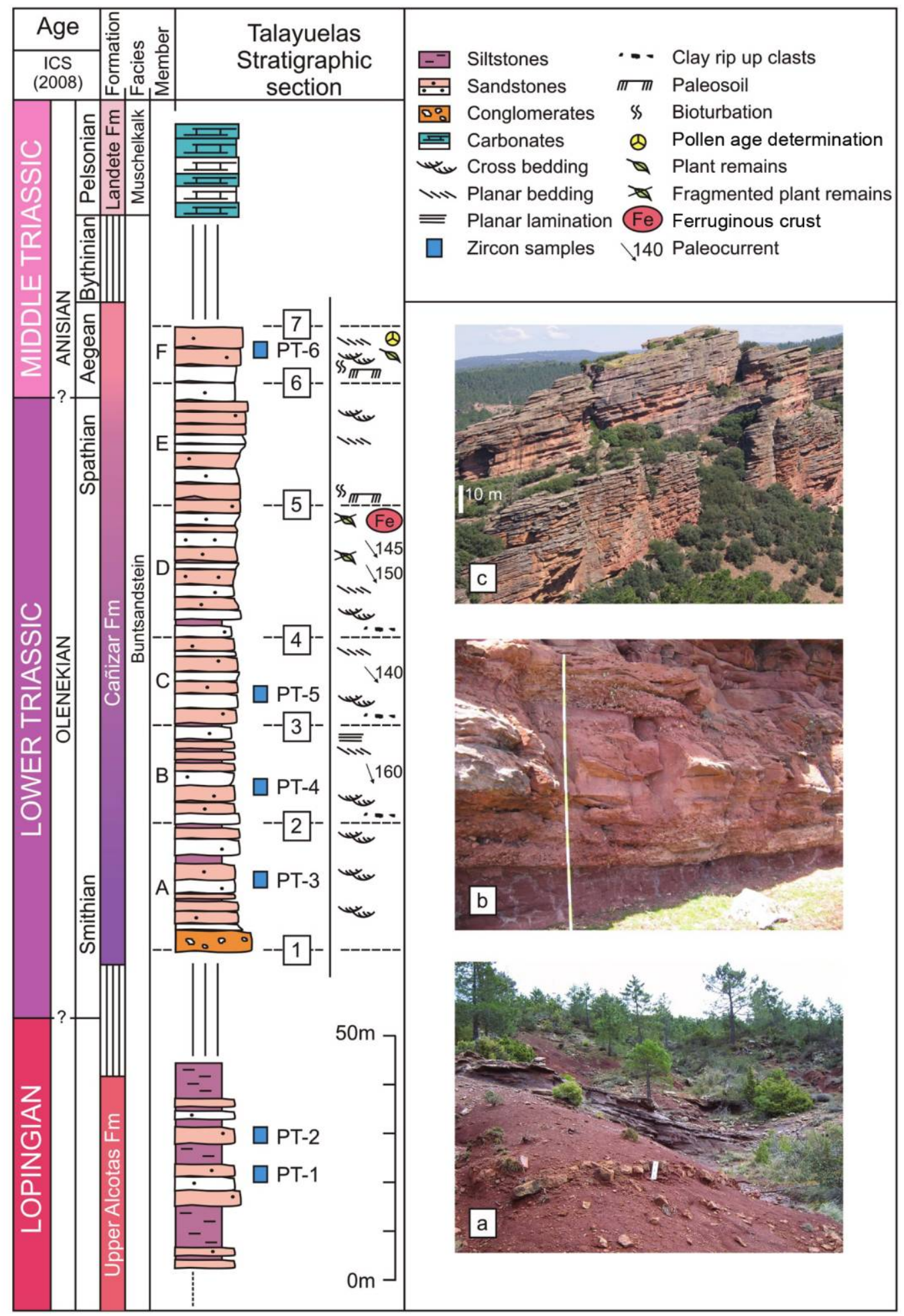

Figure 3. Talayuelas stratigraphic section showing the upper part of the Alcotas Formation, main sedimentary features of the Cañizar Formation, and sample locations. $A-F$, Members of the Cañizar Formation separated by major boundary surfaces (1-7). Field photographs of the Alcotas Formation $(a$; scale bar $=15 \mathrm{~cm})$, unconformity between the Permian siltstones of the Alcotas Formation and the Triassic conglomerates of the Valdemeca unit ( $b$; basal part of the Cañizar Formation; scale bar $=170 \mathrm{~cm}$ ), and typical aspect of the Buntsandstein Cañizar Formation in the Castilian Branch of the Iberian Ranges $(c)$. 
characteristics, type of paleosols, and plant remnants, this formation is divided into three subunits: lower (LP), middle (MP), and upper (UP), from base to top, respectively (López-Gómez et al. 2005). The LP is comprised of red sandstones and siltstones with conglomerate bodies with concave base and flat top showing planar cross-stratification and reactivation surfaces. This subunit represents mixed braided fluvial systems with paleoflows toward the SE and channels crossing wide floodplains refilled by migrating transverse bars (Arche and LópezGómez 2005). Carbonate paleosols with preservation of dolomicrite in some of their nodules were developed in the flood plains between the channel systems, indicating an arid to semiarid climate with marked seasonality (Benito et al. 2005). The sedimentary characteristics of the MP change with respect to the previous subunit. Sandstone bodies intercalated within the siltstones are basically tabular with abundant epsilon cross-bedding structures. This subunit represents sandy braided and meandering fluvial systems flowing toward the SE through broadly vegetated floodplains, where noncarbonate paleosols were developed (De la Horra et al. 2008). Preserved palynological assemblages and carbonaceous remnants of plants indicate rather humid conditions for this subunit (Diéguez et al. 2007). Finally, the UP subunit consists of siltstones with intercalated lenticular sandstone bodies with planar cross-stratification and current ripples. Macro- and microflora are absent in this subunit, and only scarce and poorly developed paleosols have been recognized (Diéguez and Barrón 2005; De la Horra et al. 2008). The UP is interpreted as a very low-energy sandy braided river system showing paleocurrents toward the SE and with a high avulsion rate, probably caused by the lack of stabilization of the banks in the absence of vegetated cover (Arche and López-Gómez 2005).

The Cañizar Formation. The sedimentation of this unit and its lateral equivalents is recorded all along the Iberian Basin as well as in most of eastern Iberia. The Cañizar Formation constitutes the lower part of the so-called Buntsandstein facieswell represented in western and central Europethat marks the beginning of the Mesozoic cycle in the Iberian Basin. The Cañizar Formation lies unconformably on the Middle-Late Permian Alcotas Formation in most of the SE Iberian Basin. The basal part of the Cañizar Formation consists of 5 $\mathrm{m}$ of conglomerate and sandstones bodies differentiated as the Valdemeca unit (fig. 3), which were deposited by gravel braided fluvial systems with poor stability of channels. The presence of ventifacts indicates some aeolian influence (Bourquin et al. 2011). Most of the Cañizar Formation was deposited in alluvial environments; it is $80-170 \mathrm{~m}$ thick, mainly comprised of red-pink fine to coarsegrained sandstones (subarkose and quartzarenite), with centimetric layers of red mudstone intercalated and almost devoid of conglomeratic bodies. It has been divided into 6 subunits (A-F; fig. 3) that can be clearly traced across long distances in the SE of the Iberian Ranges (López-Gómez and Arche 1993). Seven (numbered from 1 to 7) major boundary surfaces, representing different tectonic pulses with intervals of reduced sedimentation or hiatus, separate the subunits of the Cañizar Formation. The origin of the major boundary surfaces is probably related to the multiphase synrift period detected in the Early-Middle Triassic subsidence stage (Vargas et al. 2009). During this time, spasmodic activity of the basin boundary fault systems caused numerous episodes of lateral migration of the active channel belt and erosion of floodplain sediments culminating in the differentiation of the AF subunits. These active tectonic phases could have also influenced the longitudinal connection between segments of the rift basin and source areas to the NW, creating differential subsidence and temporary transversal highs in the sedimentary basin (López-Gómez and Arche 1993), since the subsidence rate was very small $\mid<15 \mathrm{~m} / \mathrm{m}$.yr.; Vargas et al. 2009).

From a sedimentological point of view, the lower subunits (A-D; fig. 3) are very similar and can be integrated into a main sedimentary cycle that is characterized by homogeneity in its structures and absence of other features present in the upper main cycle, such as paleosols, bioturbation, plant remnants, palynological assemblages, and vertebrate footprints that are found only in subunits $\mathrm{E}$ and $\mathrm{F}$ over most of the Iberian Basin. The two main sedimentary cycles are separated by major boundary surface 5 (fig. 3), which in the field stands out as a prominent erosive surface of probable tectonic origin. This surface marks a sudden increase of energy in the system, inferred from an increase in the size of the internal sedimentary structures and a general increase in grain size.

In a broad sense, the rocks of the Cañizar Formation are interpreted as deposited by a sandy braided fluvial system with minor aeolian influence. However, subtle changes can be observed in the sedimentary structures of each of the subunits, indicating modifications in the speed of flow and other features of the fluvial system. In general, the sediments of the Cañizar Formation show very poor fossil content, scarce paleosols, and a limited variety of sedimentary structures. Most of the de- 
posits are interpreted as infilling of fluvial channels by longitudinal and transverse bars with low preservation of fine-grained floodplain deposits (LópezGómez and Arche 1993; Arche and López-Gómez 2005). Recent studies (Bourquin et al. 2011; LópezGómez et al. 2011) prove some aeolian influence on these sediments in the so-called Castilian Branch. However, this influence is more important in the Aragonese Branch of the Iberian Basin (López Gómez et al. 2011; Soria et al. 2011) and in the Catalán-Valencia Basin (Marzo 1986), both located to the north of the study area (fig. 2). Minor internal sedimentary structures such as reactivation surfaces are frequent in the fluvial sediments, suggesting a seasonal climate control of the sedimentation, with alternating dry and rainy seasons and large discharge fluctuations that reworked the sand bars and sand flats. Similar fluvial systems have been described by others (Bourquin et al. 2006; Gibling 2006). Paleocurrents show narrow dispersion and point to the SE-SSE, indicating a pervasive axial drainage coming from source areas located to the NW (López-Gómez and Arche 1993).

\section{U-Pb Geochronology of Detrital Zircons}

Sample Selection and Analytical Methodology. Two samples from the Alcotas Formation and four from the Cañizar Formation in the stratigraphic section of the Talayuelas anticline have been selected for $\mathrm{U}-\mathrm{Pb}$ dating of detrital zircons. Detailed locations of samples in the stratigraphic series are represented in figures 1 and 3 . They correspond to fineand very fine-grained sublitharenites and, to a lesser extent, quartz-arenites, in which quartz is the dominant component $(45 \%-90 \%)$, along with detrital mica, hematite, metamorphic rock fragments, and minor amounts of feldspar. Rutile, zircon, ilmenite, tourmaline, monazite, and apatite are present as accessory minerals. In addition, Srrich aluminium-phosphate-sulphate minerals have been recognized in most samples from the Cañizar Formation (Benito et al. 2005; Galán-Abellán 2008). They appear as tiny $(<2 \mu \mathrm{m})$ crystals or as polycrystalline aggregates (up to $40 \mu \mathrm{m}$ in size) that replace large detrital micas or fragments of metamorphic rock. The clay fraction is formed predominantly by illite and minor hematite. The Kubler index (full width at half maximum of the illite 10$\AA$ reflection on X-ray diffraction traces of the $<2$ $\mu \mathrm{m}$ fraction) values range from $0.61^{\circ}$ to $0.44^{\circ} \Delta 2 \theta$ and are typical of deep diagenetic conditions.

Zircon grains were separated at the Universidad Complutense de Madrid and the Goethe Univer- sität (Frankfurt am Main) by conventional gravimetric and magnetic methods to be finally handpicked under binocular microscope. Several hundreds of crystals were selected randomly from each sample to ensure a good representation of all the populations present in them, all of which were embedded in resin mounts and polished to expose their equatorial section. The specimens in all samples are subidiomorphic crystals with rounded edges, variable in dimension (100-400 $\mu \mathrm{m})$ and color, ranging from clear to pink. Before the analyses, the internal structure of the zircon grains was studied by cathodoluminescence imaging in order to identify the different growth domains and the possible imperfections (inclusions, fractures) within them. In complex crystals showing several growth stages, only the oldest core has been analyzed in order to date the first crystallization event recorded.

The U-Pb-Th analyses of zircons were performed at the Goethe Universität during four analytical sessions, using a ThermoScientific Element 2 sector field inductively coupled plasma mass spectrometer coupled to a laser ablation system, following the method described by Gerdes and Zeh (2006, 2009). In this study, a New Wave Research UP-213 ultraviolet laser was used during part of the analyses, and a RESOlution M-50 Ar-F 193-nm excimer laser was used for the rest. Isotope data were acquired in time resolved-peak jumping-pulse counting mode over 620 mass scans during 19 seconds of background measurement, followed by 24 seconds of sample ablation. A teardrop low-volume ablation cell was used for the New Wave laser (Janousek et al. 2006; Frei and Gerdes 2009), while a two-volume ablation cell (Laurin Technic, Australia) was used for the RESOlution laser. The spot size varied from 20 to $40 \mu \mathrm{m}$ depending on the grain, and the typical penetration depth of the laser beam was $10-15 \mu \mathrm{m}$. Signal was tuned for maximum sensitivity for $\mathrm{Pb}$ and $\mathrm{U}$ while keeping oxide production, monitored as ${ }^{254} \mathrm{UO} /{ }^{238} \mathrm{O}$, well below $1 \%$. Raw data were corrected offline for background signal, common $\mathrm{Pb}$, laser-induced elemental fractionation, instrumental mass discrimination, and time-dependent elemental fractionation of $\mathrm{Pb} / \mathrm{U}$, using an in-house Microsoft Excel spreadsheet program (Gerdes and Zeh 2006, 2009). A common Pb correction based on the interference- and background-corrected ${ }^{204} \mathrm{~Pb}$ signal and a model $\mathrm{Pb}$ composition (Stacey and Kramers 1975) was applied when necessary. Laser-induced elemental fractionation and instrumental mass discrimination were corrected by normalization to the reference zircon 
GJ-1 (Jackson et al. 2004). Before this normalization, the drift in interelemental fractionation $(\mathrm{Pb} /$ $\mathrm{U})$ during 24 seconds of sample ablation was corrected for the individual analysis. The correction was done by applying a linear regression through all measured ratios, excluding the outliers $( \pm 2 \mathrm{SD})$, and using the intercept with the $Y$-axis as the initial ratio. The total offset of the measured drift-corrected ${ }^{206} \mathrm{~Pb} /{ }^{238} \mathrm{U}$ ratio from the "true" isotope dilution thermal ionization mass spectrometry (IDTIMS) value $(0.0982 \pm 0.0004$; ID-TIMS JWG value) of the analyzed GJ-1 grain was typically around $20 \%$. Reported uncertainties $(2 \sigma)$ of the ${ }^{206} \mathrm{~Pb} /{ }^{238} \mathrm{U}$ ratio were propagated by quadratic addition of the external reproducibility $(2 \mathrm{SD} \%) \mathrm{ob}$ tained from the standard zircon GJ-1 ( $n=13 ; 2 \mathrm{SD}$ $\sim 1.1 \%$ ) during the analytical sequence (55 measurements of unknowns and 13 of GJ-1 standard) and the within-run precision of each analysis after correction for the interelemental fractionation $(2$ SE \%). In the case of the ${ }^{207} \mathrm{~Pb} /{ }^{206} \mathrm{~Pb}, \mathrm{a}{ }^{207} \mathrm{~Pb}$ signaldependent uncertainty propagation was used according to Gerdes and Zeh (2009). ${ }^{235} \mathrm{U}$ was calculated by dividing ${ }^{238} \mathrm{U}$ by 137.88 and the ${ }^{207} \mathrm{~Pb} /{ }^{235} \mathrm{U}$ uncertainty by quadratic addition of the ${ }^{206} \mathrm{~Pb} /{ }^{238} \mathrm{U}$ and the ${ }^{207} \mathrm{~Pb} /{ }^{206} \mathrm{~Pb}$ uncertainty. Age calculations and the creation of concordia plots were performed using Isoplot software (Ludwig 2003). Analytical results are reported in tables A1-A6, available in the online edition or from the Journal of Geology office.

U-Pb Diagrams and Selected Age Intervals. Only within-error concordant to subconcordant analyses (90\%-110\% of concordance) have been considered for the provenance study based on detrital zircon populations. Concordia diagrams showing the U$\mathrm{Pb}$ data obtained for the six samples appear in figures 4-9. A combined binned frequency histogram and probability density distribution diagram has also been plotted for each sample. The reported ages in this type of diagram correspond to the ${ }^{206} \mathrm{~Pb} /{ }^{238} \mathrm{U}$ age for the analyses younger than $1 \mathrm{Ga}$ and the ${ }^{207} \mathrm{~Pb} /{ }^{206} \mathrm{~Pb}$ age for those older. In order to simplify the description of the zircon populations present in each sample and to facilitate their comparison, the data have been divided into different age intervals representing the main orogenic or crust-forming events. The percentage of analyses corresponding to each interval has been also represented in pie diagrams for comparative purposes.

The youngest time span corresponds to the analyses ranging from 290 to $360 \mathrm{Ma}$ and has been considered the Variscan group of ages, because this was the main period when the igneous and tectonometamorphic activity derived from the collision of
Gondwana and Laurussia took place, building the Variscan orogen (Dallmeyer et al. 1997). Older tectonometamorphic Variscan ages have been reported in some restricted units of this belt, as in the basal allochthonous units of NW Iberia. These units are considered to represent the most external margin of Gondwana, subducted below Laurussia at the onset of the Variscan deformation at ca. $370 \mathrm{Ma}$ (Abati et al. 2010b). However, these ages are uncommon in the belt, as a consequence of the limited distribution of these allochthonous units in Europe and the scarce lithologies still preserving these ages after retrogression. Using these arguments, we selected the age of $360 \mathrm{Ma}$ as representative of the most extended event dating the beginning of the Variscan activity.

The group of analyses ranging from 390 to 520 Ma has been considered Avalonian, in agreement with the age of the igneous and metamorphic activity recorded in the Avalonia microcontinent, including the activity related to the rifting of Avalonia from Gondwana and the later activity related to the collision of this microcontinent with Laurentia and Baltica previous to the accretion of Gondwana (Stampfli and Borel 2002). In addition, other unrelated crust-forming events within the same age range have been also recorded as the generation of the youngest oceanic crust in the Rheic realm, immediately before the closure of this wide Paleozoic ocean (Diaz García et al. 1999; Sánchez Martínez et al. 2007). However, the ophiolitic units with this chronology preserved in the Variscan suture have a very restricted distribution, with only minor influence on the age interval representing the Avalonian activity. More problematic is the most extended igneous activity typical of the Gondwanan margin in the interval 470-520 Ma. This magmatism generated a huge volume of granitic rocks, with ages that can be recorded now in any crustal element derived from Gondwana (ValverdeVaquero and Dunning 2000; Arenas et al. 2009; Abati et al. 2010b). Therefore, the interval 470-390 Ma can be considered even more representative and exclusive of the Avalonian microcontinent.

Zircons with ages ranging between 520 and 750 Ma have been considered Cadomian, and they represent the igneous and tectonometamorphic activity related to the Cadomian and Pan-African orogenic events, which have been recorded in the northern periphery of the Gondwana supercontinent (Nance and Murphy 1994; Linnemann et al. 2007, 2008).

The following group, including the analyses ranging between 750 and $900 \mathrm{Ma}$, has been classified 

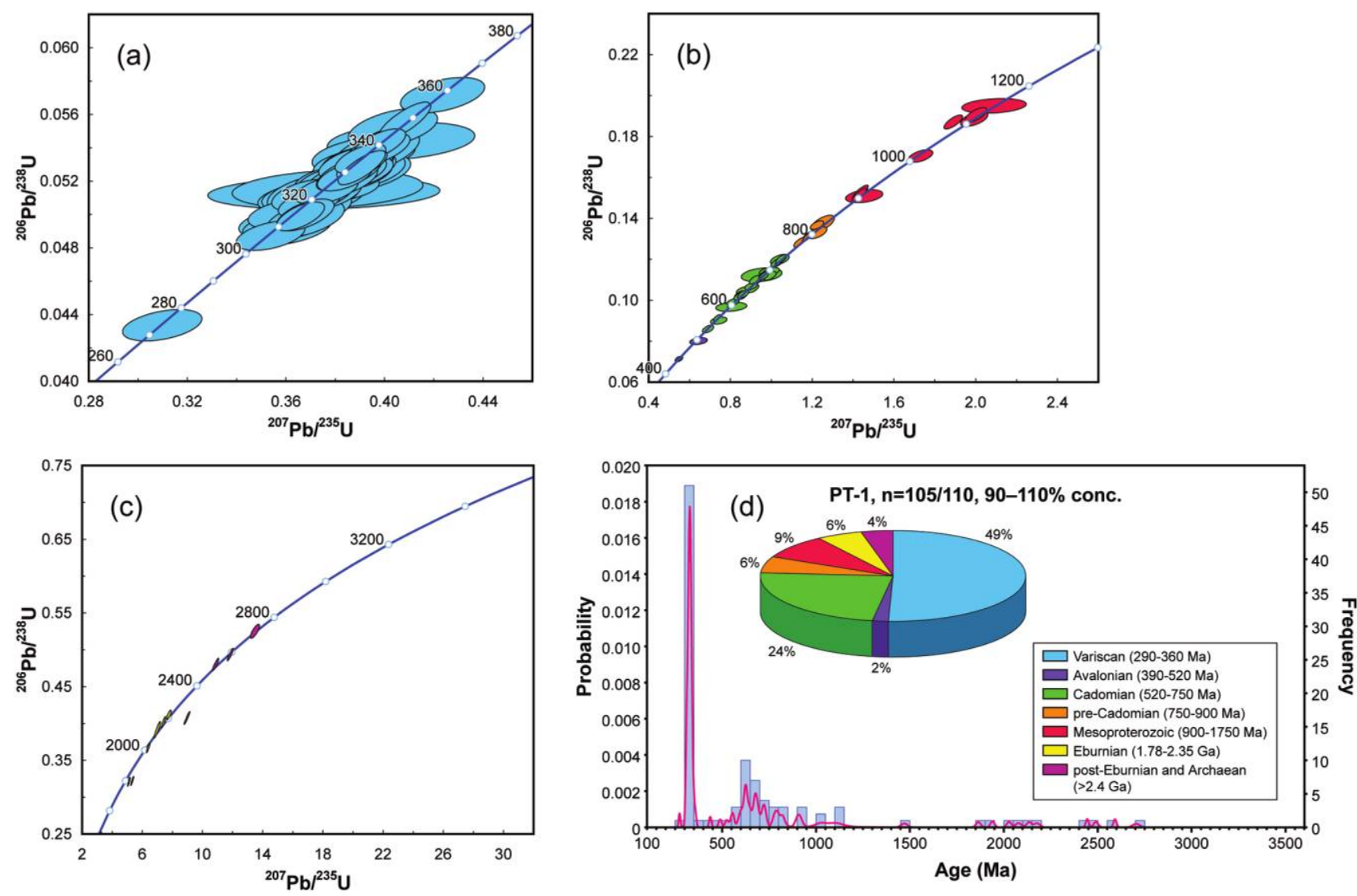

Figure 4. $a-c$, Concordia diagrams of LA-ICP-MS U-Pb analyses of detrital zircons from the sandstone sample PT1 (Alcotas Formation). $d$, Combined binned frequency histogram (blue bars) and probability density distribution diagram (pink line) of $\mathrm{U}-\mathrm{Pb}$ ages, and pie diagram of zircon populations corresponding to the main orogenic or crustforming events. Only within-error concordant or subconcordant analyses have been considered for interpretation. $\mathrm{n}$, total number of analyses considered/total number of analyzed grains; conc., concordance. The colors of the ellipses in the concordia diagrams correlate with the colors for the main zircon populations. Error ellipses are $2 \sigma$.

as pre-Cadomian. South American and African continental masses experienced rifting and collisional events almost simultaneously during this time. They are related to magmatic and tectonic activities linked to the evolution of the Pampean-GoiásPharusian-Arabian-Nubian oceanic lithosphere (Cordani et al. 2003; Kröner and Cordani 2003), including subduction-related tectonomagmatic episodes of the Pan-African/Brasiliano orogenic cycle. Furthermore, it is considered that the assembly of the supercontinent Rodinia took place during the period comprised from 1000 to $750 \mathrm{Ma}$.

The next population we distinguish here ranges from 900 to $1750 \mathrm{Ma}$, and we call it Mesoproterozoic for simplification, although it also includes a short period of Paleoproterozoic time. These ages correspond to the orogenic cycles that contributed to the growth of the Amazonian and Baltica cratons, concluding with the contemporary SunsasGrenville orogeny between 1.2 and 0.9 Ga (Bahlburg et al. 2009 and references therein) and the Sveconorwegian orogeny between 1.14 and $0.9 \mathrm{Ga}$ (Bogdanova et al. 2008), responsible for the amalgamation of these cratons into the supercontinent Rodinia. For this reason, an age gap between 1.75 and 1.0 is used to distinguish a Cadomian and/or West African provenance without influence of these orogenic cycles, from East Avalonia and Baltica (Nance and Murphy 1994; Friedl et al. 2000).

The group of ages ranging 1.78-2.35 Ga are related to orogenic cycles as the Eburnian-Birimian recorded by the West African craton (Abati et al. $2010 a$ and references therein) or the Transamazonian, which affected different Archean and Paleo- 

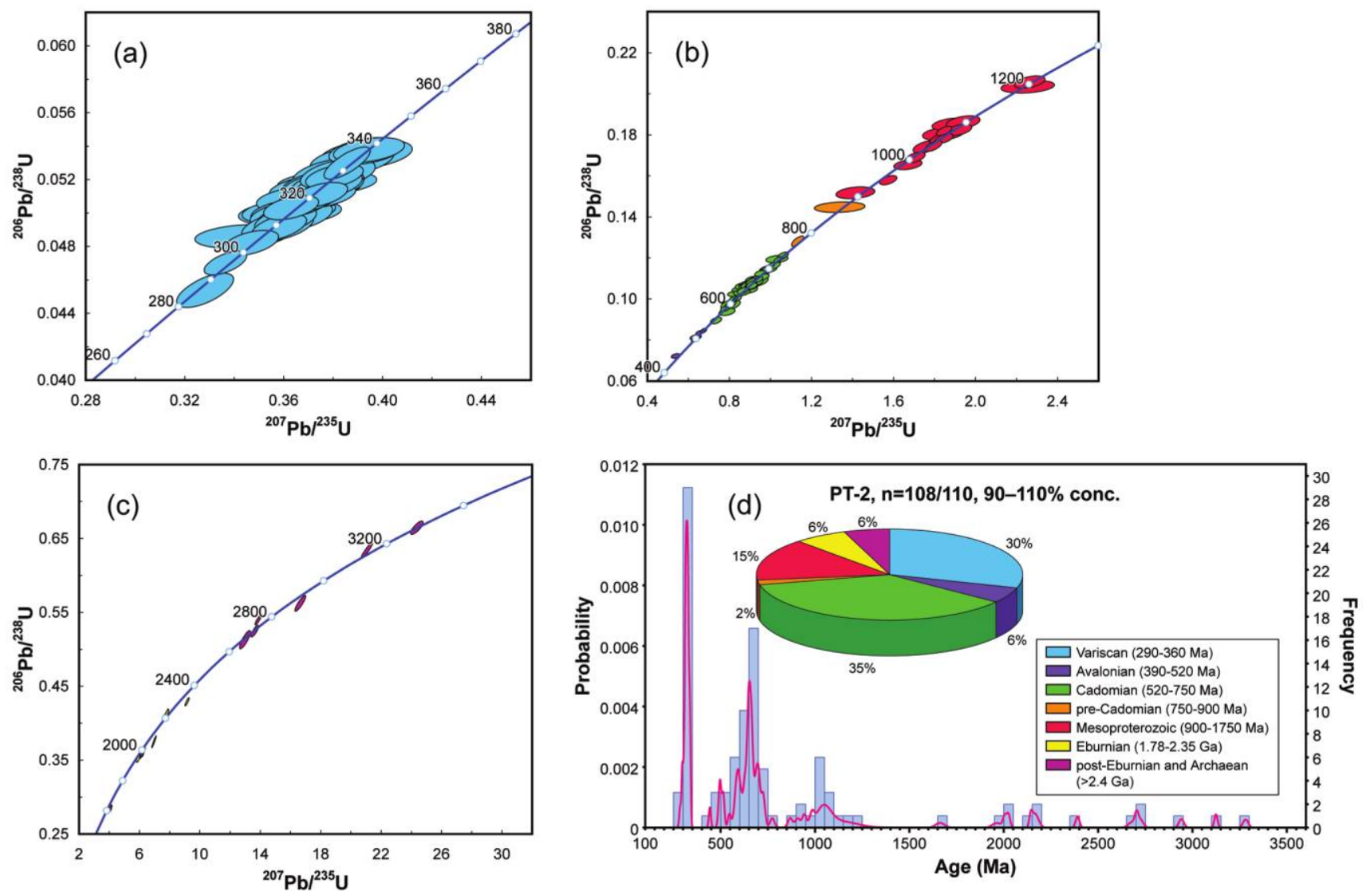

Figure 5. $a-c$, Concordia diagrams of LA-ICP-MS U-Pb analyses of detrital zircons from the sandstone sample PT2 (Alcotas Formation). d, Combined binned frequency histogram and probability density distribution diagram of U$\mathrm{Pb}$ ages, and pie diagram of zircon populations corresponding to the main orogenic or crust-forming events. Abbreviations and other features as described in figure 4. Error ellipses are $2 \sigma$.

Proterozoic cratons of South-America (Zhao et al. 2002). Finally, the ages older than 2.4 Ga are postEburnian and Archean.

Samples from the Alcotas Formation (GuadalupianLopingian, Middle-Upper Permian). Sample PT1. The most abundant population of zircons in this sample has Variscan ages (49\% from 105 concordant to subconcordant analyses), ranging from $273 \pm 5$ to $359 \pm 5 \mathrm{Ma}$ and showing a maximum in the interval between 300 and $350 \mathrm{Ma}$ (fig. 4a, 4d). The second population in importance is the Cadomian group $(24 \%, 525 \pm 9$ to $728 \pm 10 \mathrm{Ma})$, with a second relative maximum at 600-650 Ma. The rest of the populations described above are also represented but in a lower percentage, as a consequence of the dilution caused by a predominant input of the younger populations. The presence of a Mesoproterozoic population, consisting in nine analyses between $903 \pm 15$ and $1471 \pm 17 \mathrm{Ma}$, is significant (fig. $4 b, 4 d$ ).

Sample PT-2. The percentage of Variscan analyses becomes reduced in this sample (30\% from 108 analyses), with a maximum at $300-350 \mathrm{Ma}$ comprising 29 analyses. The Cadomian population experiences a relative increase to be the most abundant $35 \%$ corresponding to 39 analyses between $547 \pm 8$ and $732 \pm 8 \mathrm{Ma}$ ), with a relative maximum at $650-700 \mathrm{Ma}$ (fig. 5). There is also a significant increase of the Mesoproterozoic population up to $15 \%$ (16 analyses between $908 \pm 13$ and $1663 \pm 23 \mathrm{Ma})$. It can be deduced that a change in the sedimentary regime is taking place at the top of the Alcotas Formation.

Samples from Cañizar Formation (Olenekian-Anisian, Early-Middle Triassic). Sample PT-3. We can observe a drastic change in the zircon input in the first 
sample collected at the bottom of the Cañizar Formation. The Variscan population appears reduced to $4 \%$ while the Cadomian population becomes the most abundant, with $45 \%$ from 97 analyses. In this case, the highest abundance of zircons corresponds to the 600-650-Ma interval including 17 analyses (fig. 6). The second relative maximum occurs in the 1-1.05-Ga interval with six analyses, being the Mesoproterozoic population the second most represented in this sample $(17 \%)$. It is worth mentioning a relative increase of the pre-Cadomian (10\%), Eburnian $(10 \%)$, and post-Eburnian and Archean (9\%) populations at the expense of the reduction of the Variscan group of zircons. The change of sedimentary regime initiated at the top of the Alcotas Formation is fully established at the bottom of Cañizar. The source of the detrital zircons supplied to the sample PT-3 must have changed.

Sample PT-4. The predominant population in this sample still corresponds to the Cadomian group $\left(38 \%\right.$ from 114 analyses with ${ }^{206} \mathrm{~Pb} /{ }^{238} \mathrm{U}$ ages between $521 \pm 11$ and $718 \pm 10 \mathrm{Ma}$ ), with a maximum in the interval of 600-650 Ma (fig. 7). The increase of the Avalonian population, up to $13 \%$, is remarkable, although it was always present in the previous samples but in a minor percentage. In this case, the second relative maximum corresponds also to this group, with 13 analyses between 450 and $500 \mathrm{Ma}$. The remaining populations of importance are the pre-Cadomian $(20 \%)$ and Mesoproterozoic $(11 \%)$.

Sample PT-5. This sample resembles the two previously described. Once again, the Cadomian population is predominant, with $44 \%$ from 106 analyses with ${ }^{206} \mathrm{~Pb} /{ }^{238} \mathrm{U}$ ages ranging from $526 \pm$ 7 to $738 \pm 11 \mathrm{Ma}$. The maximum abundance occurs within the interval between 650 and $700 \mathrm{Ma}$, with a total of 16 analyses. The Avalonian population $(7 \%)$ decreases compared with the sample PT-4, while the Mesoproterozoic remains similar
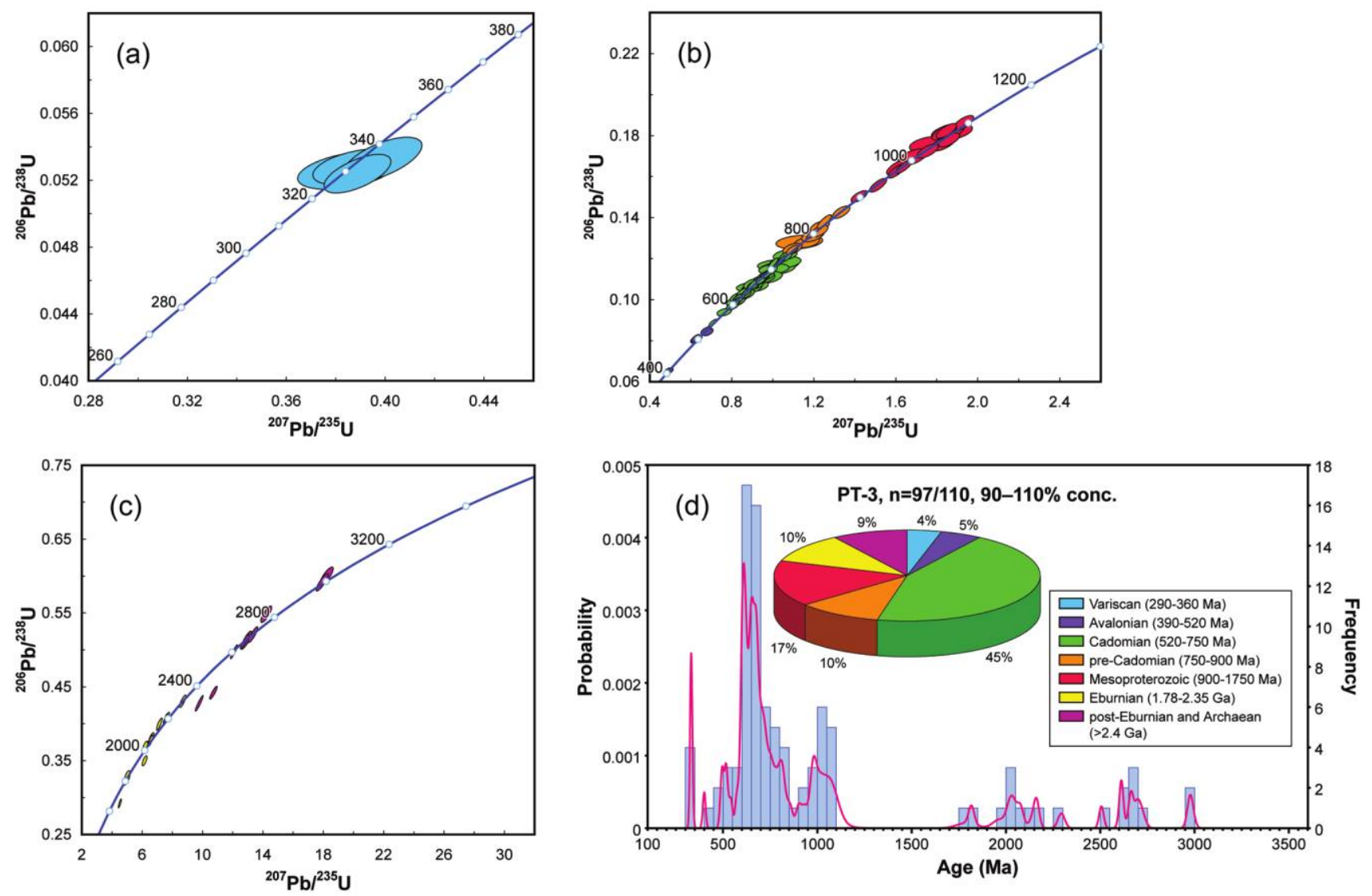

Figure 6. $a-c$, Concordia diagrams of LA-ICP-MS U-Pb analyses of detrital zircons from the sandstone sample PT3 (Cañizar Formation). $d$, Combined binned frequency histogram and probability density distribution diagram of U$\mathrm{Pb}$ ages, and pie diagram of zircon populations corresponding to the main orogenic or crust-forming events. Abbreviations and other features as described in figure 4. Error ellipses are $2 \sigma$. 

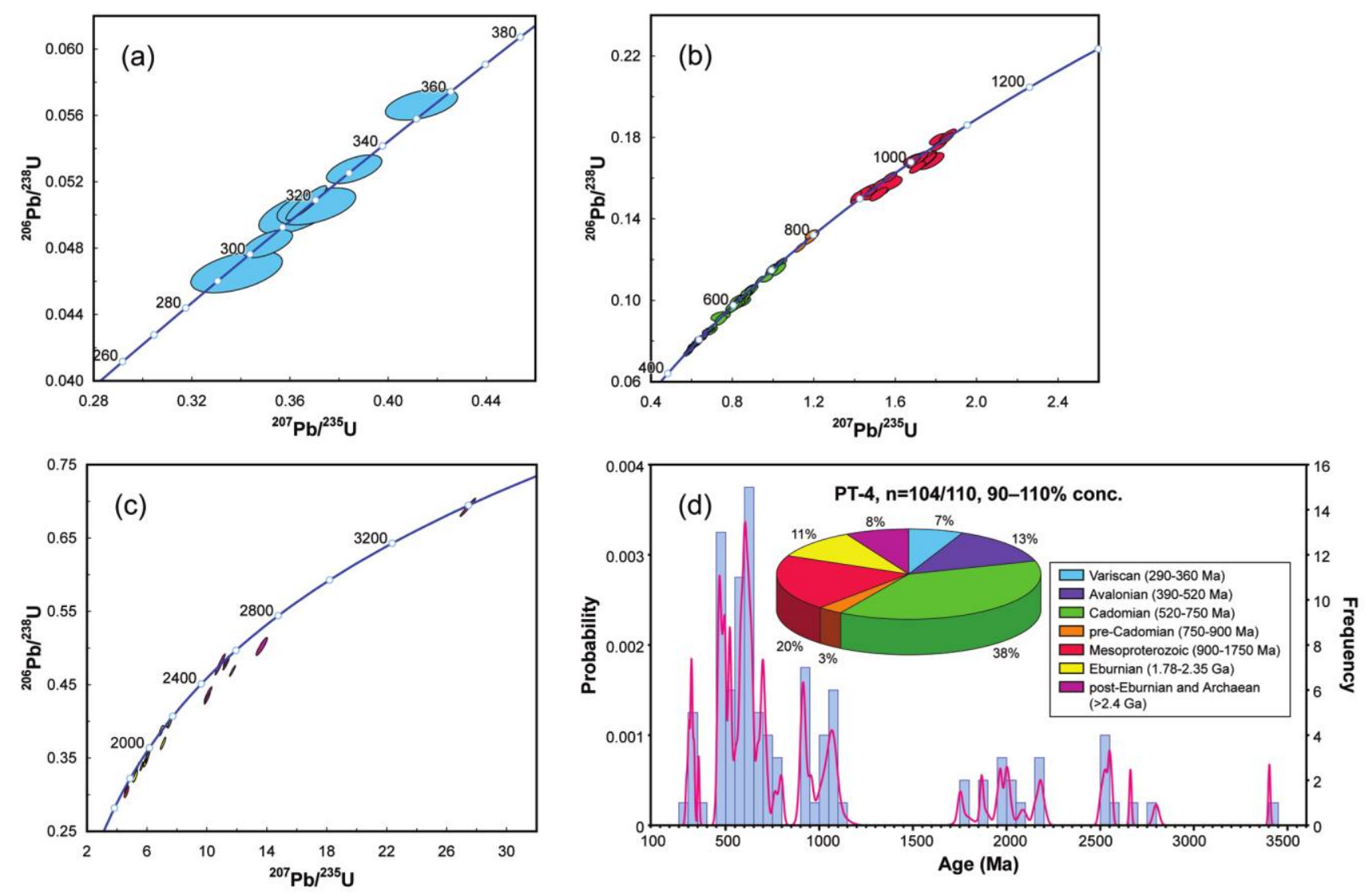

Figure 7. $a-c$, Concordia diagrams of LA-ICP-MS U-Pb analyses of detrital zircons from the sandstone sample PT4 (Cañizar Formation). $d$, Combined binned frequency histogram and probability density distribution diagram of U$\mathrm{Pb}$ ages, and pie diagram of zircon populations corresponding to the main orogenic or crust-forming events. Abbreviations and other features as described in figure 4. Error ellipses are $2 \sigma$.

(19\%), with 20 analyses between $938 \pm 21$ and $1753 \pm 16 \mathrm{Ma}$. The Eburnian and post-Eburnian and Archean populations appear represented, with $10 \%$ and $12 \%$ of the total analyses, respectively, and the Variscan group is very scarce (fig. 8).

Sample PT-6. This sample located at the top of the Cañizar Formation records a new drastic change in the input of detrital zircons. The abundance of the different populations resembles that recorded by the sample PT- 1 of Alcotas Formation. The most abundant population corresponds again to the Variscan ages, with $50 \%$ of 100 analyses ranging between $297 \pm 4$ and $348 \pm 7 \mathrm{Ma}$ and a peak corresponding to the interval of 300-350 Ma, including 44 analyses (fig. 9). The Cadomian population experiences a corresponding reduction to $28 \%$, displaying a second relative maximum at 600-700 Ma. The rest of the populations, although present, have experienced a significant decrease, with percentages ranging from $5 \%$ to $3 \%$. Accord- ing to this data, it is clear that a major change in the sedimentary regime and the source of the detrital zircons has taken place at the top of the Cañizar Formation.

\section{Discussion}

A paleogeographic reconstruction for the North Atlantic region by the final Variscan convergence (Middle Carboniferous) is shown in figure 10. In this context, the paleoposition of continents remained almost unchanged until Middle Triassic times. The paleogeography of the Late PaleozoicEarly Mesozoic shown in figure 10 is based on the continental reconstructions published by Martínez Catalán et al. (2002, 2009) and Stampfli and Borel (2002). The most schematic reconstruction of Simancas et al. (2009) is shown in figure 11. They show the distribution of the continents amalgamated during the long period of convergence and 

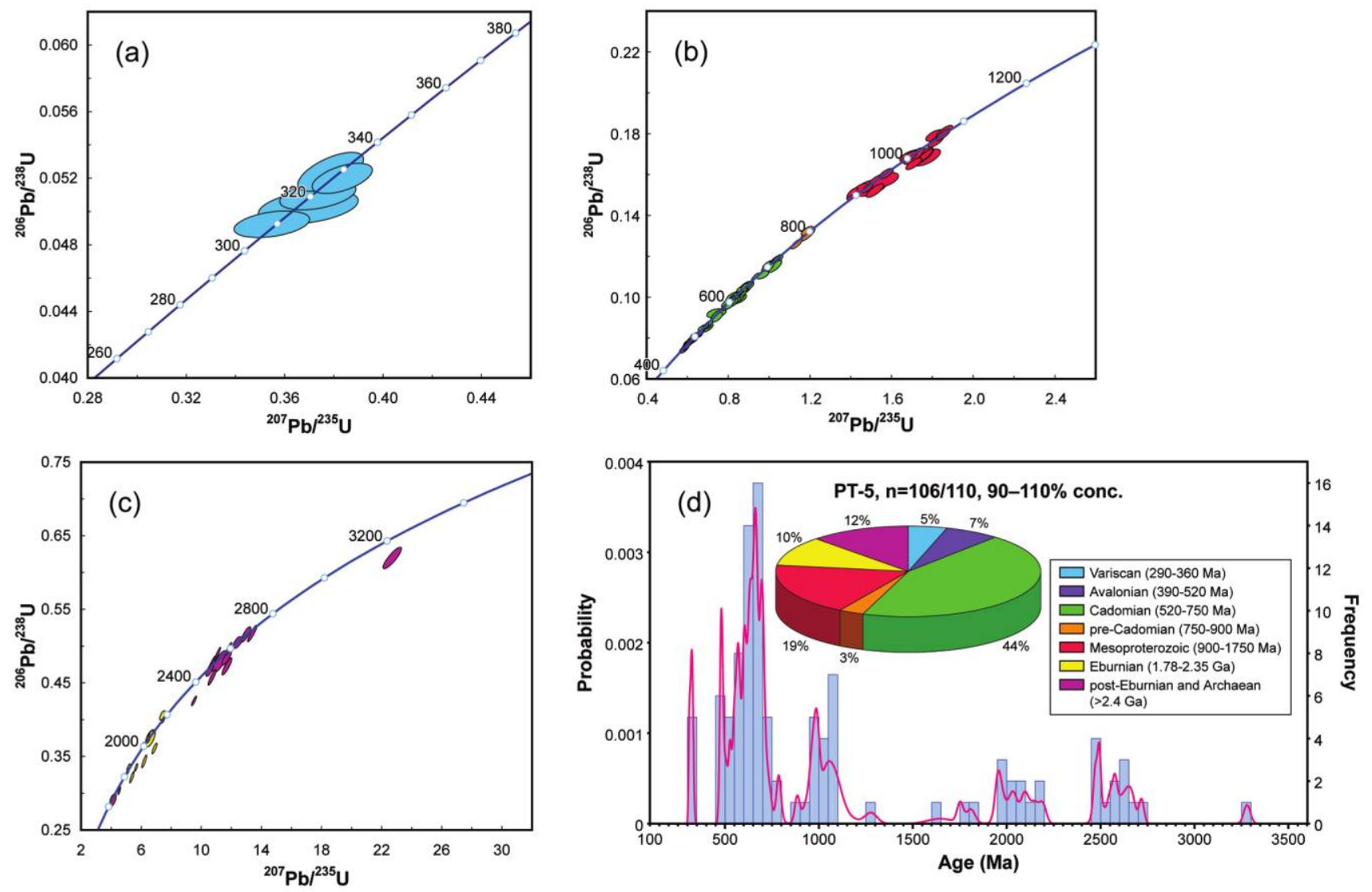

Figure 8. $a-c$, Concordia diagrams of LA-ICP-MS U-Pb analyses of detrital zircons from the sandstone sample PT5 (Cañizar Formation). d, Combined binned frequency histogram and probability density distribution diagram of U$\mathrm{Pb}$ ages, and pie diagram of zircon populations corresponding to the main orogenic or crust-forming events. Abbreviations and other features as described in figure 4 . Error ellipses are $2 \sigma$.

collisions that caused the final assembly of Pangea. Four continents appear in this reconstruction: Laurentia, Baltica, Gondwana, and Avalonia. Avalonia is the smallest and is considered a terrane derived from the peri-Gondwanan realm, rifted from the main continent at the same time as other minor terranes in Late Cambrian-Early Ordovician times (Nance et al. 2010). The oldest event of convergence represented in figure 10 is the collision between Baltica and Laurentia, as a consequence of the closure of the northern branch of the Iapetus Ocean in Early Silurian times (Llandovery) that formed the Caledonian belt of Scandinavia and Greenland (Stampfli and Borel 2002). The southern branch of the Iapetus Ocean and its eastern continuation along the Tornquist Ocean closed during the continental convergence that finally caused the accretion of Avalonia and other minor peri-Gondwanan terranes to the southern margin of Laurentia-Baltica in Middle-Late Silurian times, forming Lau- russia (Murphy et al. 2010; Nance et al. 2010). Later on, new convergence between Laurussia and Gondwana caused the closure of the oceanic domain generated to the south of Avalonia, the Rheic Ocean (Arenas et al. 2007; Sánchez Martínez et al. 2007), and the collisional event that ended the Pangea assembly in Late Devonian-Early Carboniferous times (Martínez Catalán et al. 2009; Abati et al. 2010b; Díez Fernández et al. 2011). The VariscanAppalachian belt was formed during this final collision, and it is one of the most relevant elements in order to reconstruct the position of the continents amalgamated in Pangea. In detail, this final assembly event is complex, and different models have been proposed. Von Raumer et al. (2003) and Von Raumer and Stampfli (2008) described a first stage with collision of peri-Gondwanan terranes (Late Devonian-Early Carboniferous), followed by a final collision of Gondwana and Laurussia in Late Carboniferous times. In contrast, others authors de- 

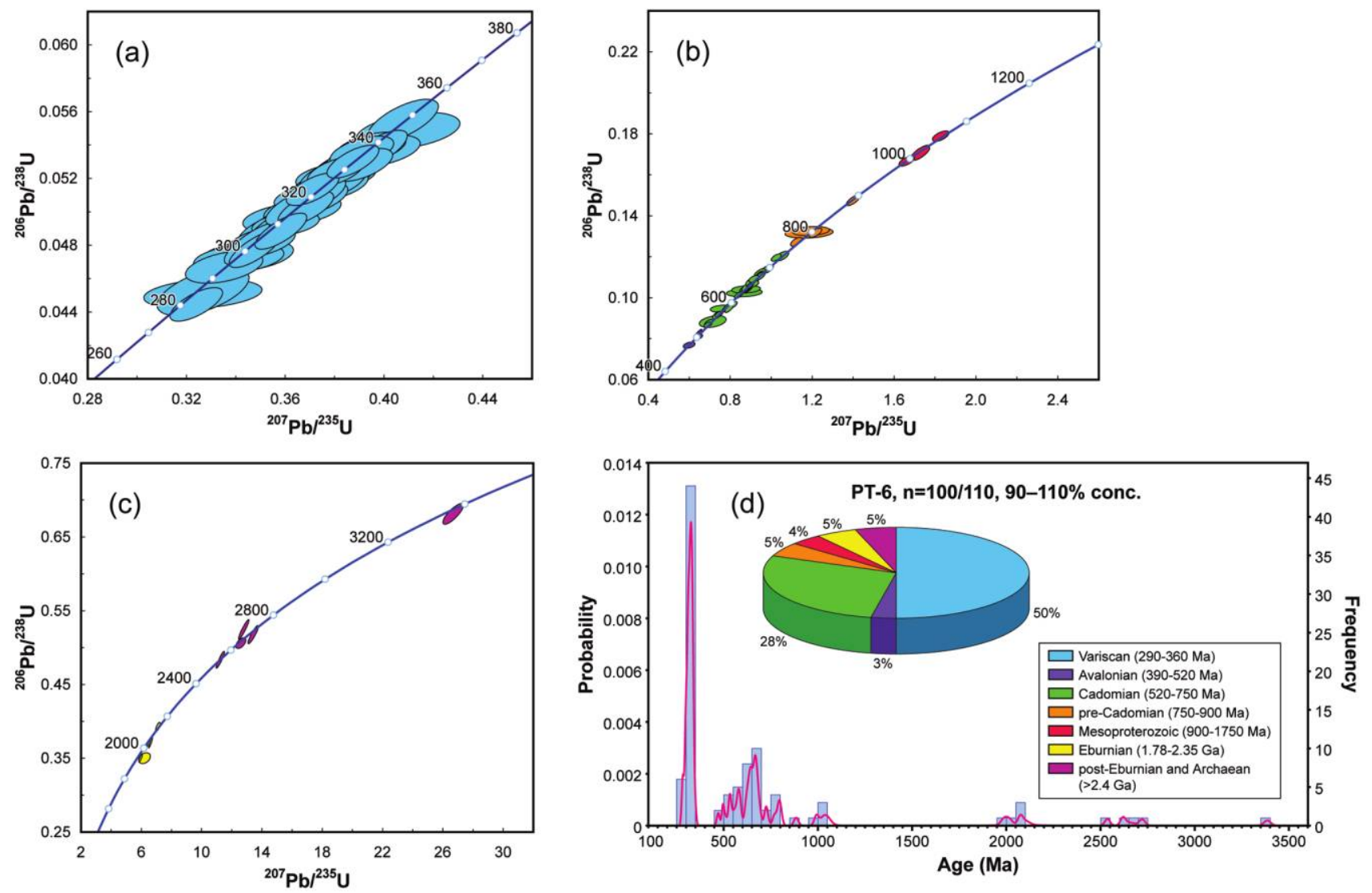

Figure 9. $a-c$, Concordia diagrams of LA-ICP-MS U-Pb analyses of detrital zircons from the sandstone sample PT6 (Cañizar Formation). $d$, Combined binned frequency histogram and probability density distribution diagram of U$\mathrm{Pb}$ ages, and pie diagram of zircon populations corresponding to the main orogenic or crust-forming events. Abbreviations and other features as described in figure 4. Error ellipses are $2 \sigma$.

scribed a partly different scenario defined by frontal continental collision in Late Devonian-Early Carboniferous times, with a less important participation of peri-Gondwanan terranes (Martínez Catalán et al. 2004, 2009).

In the North Atlantic domain, the opening of the Permo-Triassic sedimentary basins is related to the initial development and later propagation of long rift structures that finally caused the breakup of Pangea (Ziegler 1982, 1988; López Gómez et al. 2002). New research focused on the study of the provenance of the Permo-Triassic sediments, using $\mathrm{U}-\mathrm{Pb}$ geochronology of detrital zircons, can provide information not only about the source areas for these sediments but also about the dynamics and evolution of the rift systems. In this context, the distribution of continents in the North Atlantic region at the end of the Carboniferous period and their different tectonothermal histories define a perfect setting for a provenance study. The paleo- margin of Gondwana, the Variscan belt, and Avalonia show a roughly E-W orientation, also subparallel to the southern margin of Laurentia-Baltica (fig. 11). Moreover, this continent's distribution is oblique to the main Permo-Triassic rift that generated the Iberian Basin, which is characterized by paleocurrents suggesting a systematic provenance from the N-NW (figs. 1, 3). This general context will be considered in order to interpret the provenance of the detrital zircons included in the PermoTriassic sediments of the Iberian Ranges.

The two samples of Late Permian sediments (PT1 and PT-2) include significant (PT-2) or dominant (PT-1) populations of zircons of Variscan age (290$360 \mathrm{Ma}$ ). This fact suggests that their source area was located in the axial zone of the Variscan belt, probably in the core of the Ibero-Armorican arc if the orientation of the Permian basin and the direction of the paleocurrents are considered (fig. 11). In Iberia, this axial zone is mainly represented by 


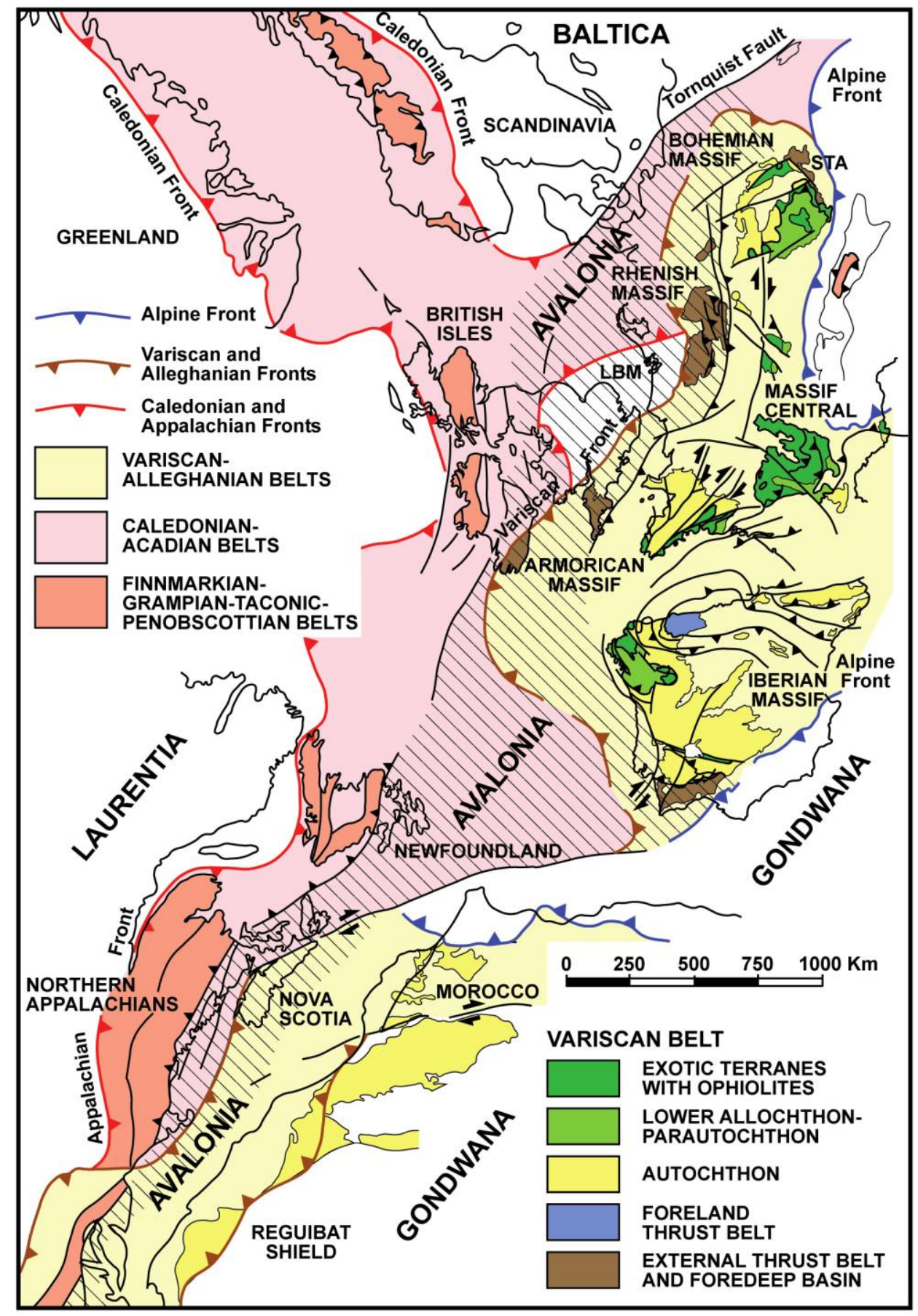

Figure 10. Sketch showing the distribution of Paleozoic orogens in a reconstruction of the Baltica-Laurentia-Gondwana junction that developed during the assembly of Pangea (final Variscan convergence). The distribution of the most important domains described in the Variscan Belt is also shown, together with the inferred position of the microcontinent Avalonia. LBM, London-Brabant Massif; STA, Silesian Terrane Assemblage. 

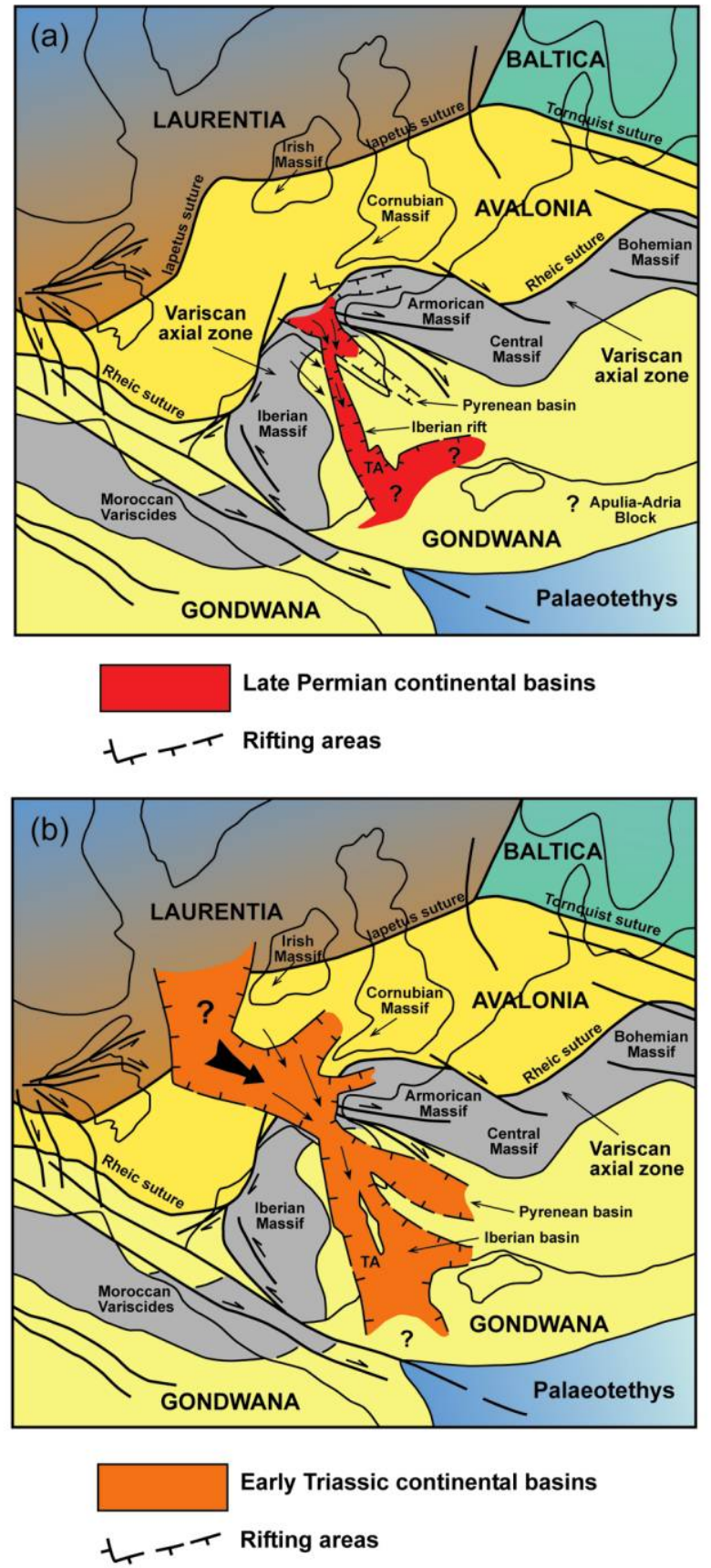

Figure 11. Sketch showing the distribution of the Permo-Triassic intracontinental basins and rift systems in the Iberia realm and surrounding areas. The arrows show the paleocurrents and the evolution of the source areas through time.

the Galicia-Trás-os-Montes Zone, the Central Iberian Zone, and the most western part of the West Asturian-Leonese Zone (Martínez Catalán et al. 2009). This axial zone is considered the main source area for Variscan zircons, since this is the region where high-grade Variscan metamorphism and the most important granitic magmatism occurred. Both samples also show important populations of Cadomian zircons $(520-750 \mathrm{Ma})$, but these zircons are only indicative for an initial Gondwanan provenance for the involved terranes, which is the case for all the lithologies included in the Variscan axial zone and also for Avalonia. The presence of Mesoproterozoic zircons, important in sample PT-2, would suggest that part of the source areas was located in Avalonia, where this group of ages is common (Linnemann et al. 2004). However, considering that the Mesoproterozoic population also exists in the Neoproterozoic, Cambrian, and Ordovician sediments from the Iberian basement (Fernández Suárez et al. 2000, 2002; Martínez Catalán et al. 2004; Díez Fernández et al. 2010), it is not possible to indicate a more detailed location for the source of Late Permian materials. Therefore, detrital zircon age data of the Late Permian sediments from the Talayuelas anticline indicate a relationship with long fluvial systems that would start at least in the core of the Ibero-Armorican arc and followed the direction of the active Iberian rift, with NW-SE orientation.

The most important feature of the three samples of Lower Triassic sediments (PT-3, PT-4, and PT-5) is a drastic decrease in the amount of Variscan zircons, showing a content of $4 \%-7 \%$. This general decrease is compensated by the increase of Cadomian zircons $(38 \%-45 \%)$ and, to a lesser extent, by an increase of the Mesoproterozoic (17\%-20\%), Eburnian (10\%-11\%), and post-Eburnian and Archaean $(8 \%-12 \%)$ populations. At first, the almost complete absence of Variscan zircons suggests that the main source areas were located further away from the Variscan axial zone, either to the NW or at the most inner part of the Ibero-Armorican arc, a region belonging to the external zones of the Variscan belt, where no important igneous or metamorphic activity exists. The second possibility would imply an important decrease in the length and significance of the Lower Triassic fluvial systems in relation to those of the Permian, which is not supported by the sedimentological data showing sandy braided river deposits, almost devoid of fines, with paleocurrents very consistent to the S$\mathrm{SE}$, and no evidence of minor transverse streams, all indicative of very long and extensive fluvial systems (Arche and López Gómez 2005). On the other hand, the significant increment on the contents of Avalonian, Mesoproterozoic, Eburnian, and postEburnian and Archaean zircon populations are at 
first more typical of source areas located to the NW of the Variscan axial zone, that is, at least in the Avalonian terrane (fig. 11). In this regard, it is also important to point out that sample PT-4, with the highest content in Avalonian zircons (13\%), includes a group of zircons with ages ranging 458$479 \mathrm{Ma}(n=8)$. These ages are almost unknown in the Variscan axial zone or the external zones of the Variscan belt, and they seem to confirm that the most important source areas for the Lower Triassic sediments were located in Avalonia (fig. 11).

It is more difficult to interpret whether some source areas for the Lower Triassic series could be located in Laurentia. In this regard, the significant increase in Mesoproterozoic, Paleoproterozoic, and Archaean zircons could support this interpretation, since all these zircon populations are typical of Laurentia. However, both Laurentia and Baltica did not register any significant Cadomian activity (Nance et al. 2007), which can be considered the most important in the source areas of the Triassic sediments. The age populations recorded in the studied detrital zircons do not allow us to rule out completely that some source areas might be located in the southernmost part of Laurentia. However, the provenance from this region would be limited.

The age populations obtained in the detrital zircons from the Middle Triassic sediments show again a drastic change in the location of the source areas. Sample PT-6 is characterized by predominance of Variscan zircons $(50 \%)$, which in this case reach the highest content found in the six Permo-Triassic samples here studied. The age populations obtained in sample PT-6 are almost identical to those described in the sample PT-1 collected from the Late Permian deposits. In this case, the source area for these sediments can be assigned easily again to a sector located at the axial zone of the Variscan belt, in the core of the Ibero-Armorican arc.

The new U-Pb data obtained in detrital zircons of Permo-Triassic sediments from the Iberian Ranges can be interpreted in a dynamic setting related to the development of a large intracontinental rift system (López Gómez et al. 2002; Stamfli and Borel 2002). The advance of the extensional tectonics associated with the activity of this rift system caused the inception of the breakup of Pangea and the development of progressively larger sedimentary basins that concentrated the Mesozoic marine sedimentation in the North Atlantic context (Stampfli and Borel 2002, 2004). The sedimentation of the Late Permian deposits is linked to the beginning of the extensional activity in the Iberian rift (fig. 11). The source area for these materials was placed over the axial zone of the Variscan belt lo- cated in the core of the Ibero-Armorican arc, which probably suggests either that the rift system did not exist yet to the north of this sector or that its development was still limited. The source areas for the Lower Triassic sediments were located mainly in Avalonia, with a possible and limited contribution from source areas located in the southern part of Laurentia. The evolution between Late Permian and Lower Triassic times suggests that the activity in the rift system advanced toward the NW and that extensional systems were probably established by this time in all the different continental blocks amalgamated in Pangea in the North Atlantic sector. The source areas of the Middle Triassic sediments were located again in the axial zone of the Variscan belt, indicating that the sedimentary supplies coming from Avalonia had stopped. This fact could suggest an important decrease in the activity of the Triassic fluvial systems. It might also indicate that the sedimentary supplies coming from the region located to the NW of Iberia were stopped by tectonic activity. In this context, the progressive development of the rift system and the consequent progress of the breakup of Pangea could modify the continuity of the Iberian rift toward the NW after the Lower Triassic. New detrital zircon data from other Permo-Triassic basins are necessary in order to advance in the interpretation of the complex relationships existing between rift development and opening of the Permo-Triassic sedimentary basins.

The new U-Pb data of detrital zircons from Permo-Triassic sediments of the Iberian Ranges supply important and new information about the source areas for these series. Moreover, the methodology used in this study is useful for the investigation of the development of these intracontinental sedimentary basins. The extension of this type of research to other Permo-Triassic basins may supply key data about their relationships with the large rift systems that finally caused the breakup of Pangea in the North Atlantic domain.

\section{Conclusions}

$\mathrm{U}-\mathrm{Pb}$ data of detrital zircons of Permo-Triassic sediments from the Talayuelas anticline (Iberian Ranges) suggest important changes in the location of the source areas through time. In the case of the Late Permian sediments, it was located to the NW, in the axial zone of the Variscan belt placed in the core of the Ibero-Armorican arc. The Lower Triassic series have source areas located further to the NW, mainly in Avalonia, with possible additional and limited supplies coming from the southernmost part of Laurentia. During Middle Triassic times, the 
source areas were located again at the axial zone of the Variscan belt.

The change of location of the source areas is considered as related to the development of intracontinental rift systems that finally caused the breakup of Pangea. The evolution of the sedimentation between Late Permian and Lower Triassic times is a consequence of the propagation of the Iberian rift to the NW, probably reaching the southern part of Laurentia. During the Middle Triassic, the sedimentary supplies along this rift experienced an important reduction, and the source areas were located again in the axial zone of the Variscan belt. New data are necessary in order to fully interpret this final part of the evolution, which might be linked either to environmental conditions or to the advance of the breakup of Pangea and the interaction of different intracontinental rift systems active in the North Atlantic region.

\section{A C K N O W L E D G M E N T S}

S. Sánchez Martínez thanks the Spanish Ministerio de Ciencia e Innovación, which provided her with a 2-yr postdoctoral contract to Goethe Universität (Frankfurt am Main). Thanks also to G. Brey for kindly hosting and welcoming us to the Department of Mineralogy and Petrology (Frankfurt) and to M. I. Benito for field support. G. Stampfli and an anonymous reviewer are gratefully acknowledged for insightful reviews of the manuscript. Thanks also to J. Alcock for a final revision of the English language. Financial support for this research has been provided by Spanish projects CGL2008-00093, CGL2010-09503E, and CGL200765338-CO2-01/BTE (Ministerio de Ciencia e Innovación). This study is also a contribution to project IGCP 597, "Amalgamation and Breakup of Pangea: The Type Example of the Supercontinent Cycle."

\section{R E F E R E N C E S}

$\rightarrow$ Abati, J.; Aghzer, A. M.; Gerdes, A.; and Ennih, N. 2010a. Detrital zircon ages of Neoproterozoic sequences of the Moroccan Anti-Atlas belt. Precambrian Res. 181: $115-128$.

$\rightarrow$ Abati, J.; Gerdes, A.; Fernández Suárez, J.; Arenas, R.; Whitehouse, M. J.; and Díez Fernández, R. 2010b. Magmatism and early-Variscan continental subduction in the northern Gondwana margin recorded in zircons from the basal units of Galicia, NW Spain. Geol. Soc. Am. Bull. 122:219-235.

$\rightarrow$ Arche, A., and López-Gómez, J. 2005. Sudden changes in fluvial style across the Permian-Triassic boundary in the eastern Iberian Ranges, Spain: analysis of possible causes. Palaeogeogr. Palaeoclimatol. Palaeoecol. 229: 104-126.

$\rightarrow$ Arenas, R.; Martínez Catalán, J. R.; Sánchez Martínez, S.; Fernández Suárez J.; Andonaegui, P.; Pearce, J. A.; and Corfu, F. 2007. The Vila de Cruces ophiolite: a remnant of the early Rheic Ocean in the Variscan suture of Galicia (NW Iberian Massif). J. Geol. 115:129148.

Arenas, R.; Sánchez Martínez, S.; Castiñeiras, P.; Jeffries, T. E.; Díez Fernández, R.; and Andonaegui, P. 2009. The basal tectonic mélange of the Cabo Ortegal Complex (NW Iberia Massif): a key unit in the suture of Pangea. J. Iberian Geol. 35:85-125.

Arribas, J.; Marfil, R.; and De la Peña, J. A. 1985. Provenance of Triassic feldspathic sandstones in the Iberian Range (Spain): significance of quartz types. J. Sediment. Petrol. 55:864-868.

Bahlburg, H.; Vervoort, J. D.; Du Frane, S. A.; Bock, B.; Augustsson, C.; and Reimann, C. 2009. Timing of crust formation and recycling in accretionary orogens: insights learned from the western margin of South America. Earth-Sci. Rev. 97:215-241.

$\rightarrow$ Benito, M. I.; De la Horra, R.; Barrenechea, J. F.; LópezGómez, J.; Rodas, M.; Alonso Azcárate, J.; Arche, A.; and Luque F. J. 2005. Late Permian in the SE Iberian Ranges, eastern Spain: petrological and mineralogical characteristics and palaeoenvironmental significance. Palaeogeogr. Palaeoclimatol. Palaeoecol. 229:24-39.

$\rightarrow$ Bogdanova, S. V.; Bingen, B.; Gorbatschev, R.; Kheraskova, T. N.; Kozlov, V. I.; Puchkov, V. N.; and Volozh, Y. A. 2008. The East European Craton (Baltica) before and during the assembly of Rodinia. Precambrian Res. 160:23-45.

$\rightarrow$ Bourquin, S.; Bercovici, A.; López-Gómez, J.; Diez, J. B.; Broutin, J.; Ronchi, A.; Durand, M.; Arché A.; Linol, B.; and Amour, F. 2011. The Permian-Triassic transition and the onset of Mesozoic sedimentation at the northwestern peri-Tethyan domain scale: palaeogeographic maps and geodynamic implications. Palaeogeogr. Palaeoclimatol. Palaeoecol. 299:265-280.

Bourquin, S.; Durand, M.; Diez, J. B.; Broutin, J.; and Fluteau, F. 2007. The Permian-Triassic boundary and lower Triassic sedimentation in the Western European basins: an overview. J. Iberian Geol. 33:221-236.

$\rightarrow$ Bourquin, S.; Péron, S.; and Durand, M. 2006. Lower Triassic sequence stratigraphy of the western part of the Germanic Basin (west of Black Forest): fluvial system evolution through time and space. Sediment. Geol. 186:187-211.

$\rightarrow$ Cordani, U. G.; D'Agrella-Filho, M. S.; Brito-Neves, B. B.; and Trindade, R. I. F. 2003. Tearing up Rodinia: the Neoproterozoic paleogeography of South American cratonic fragments. Terra Nova 15:350-359.

$\rightarrow$ Dallmeyer, R. D.; Martínez Catalán, J. R.; Arenas, R.; Gil 
Ibarguchi, J. I.; Gutiérrez Alonso, G.; Farias, P.; Bastida, F.; and Aller, J. 1997. Diachronous Variscan tectonothermal activity in the NW Iberian Massif: evidence from ${ }^{40} \mathrm{Ar} /{ }^{39} \mathrm{Ar}$ dating of regional fabrics. Tectonophysics 277:307-337.

De la Horra, R.; Benito, M. I.; López-Gómez, J.; Arche, A.; Barrenechea, J. F.; and Luque, F. J. 2008. Palaeoenvironmental significance of Late Permian paleosols in the SE Iberian Ranges, Spain. Sedimentology 55:18491873.

$\rightarrow$ De Vicente, G.; Vegas, R.; Muñoz-Martín, A.; Van Wees, J. D.; Casas-Sainz, A.; Sopeña, A.; Sánchez-Moya, Y.; Arche, A.; López-Gómez, J.; and Fernández-Lozano, J. 2009. Oblique strain partitioning and transpression on an inverted rift: the Castilian branch of the Iberian Chain. Tectonophysics 470:224-242.

$\rightarrow$ Díaz García, F.; Arenas, R.; Martínez Catalán, J. R.; González del Tánago, J.; and Dunning, G. R. 1999. Tectonic evolution of the Careón ophiolite (northwest Spain): a remnant of oceanic lithosphere in the Variscan Belt. J. Geol. 107:587-605.

$\rightarrow$ Diéguez, C., and Barrón, E. 2005. Late Permian flora and vegetation changes near the Permian-Triassic boundary in the Landete section of the Alcotas Formation (SE Iberian Ranges, Spain). Palaeogeogr. Palaeoclimatol. Palaeoecol. 229:54-68.

$\rightarrow$ Diéguez, C.; De la Horra, R.; López-Gómez, J.; Benito, M. I.; Barrenechea, J.; and Arche, A. 2007. Late Permian plant assemblages in the SE Iberian Ranges, Spain: biodiversity and palaeogeographical significance. C. R. Palevol 6:403-411.

$\rightarrow$ Díez Fernández, R.; Martínez Catalán, J. R.; Abati, J.; Arenas, R.; and Fernández-Suárez, J. 2010. U-Pb ages of detrital zircons from the Basal allochthonous units of NW Iberia: provenance and paleoposition on the northern margin of Gondwana during the Neoproterozoic and Paleozoic. Gondwana Res. 18:385-399.

Díez Fernández, R.; Martínez Catalán, J. R.; Arenas, R.; and Abati, J. 2011. Tectonic evolution of a continental subduction-exhumation channel: Variscan structure of the basal allochthonous units in NW Spain. Tectonics 30:TC3009.

$\rightarrow$ Doubinger, J.; López-Gómez, J.; and Arche, A. 1990. Pollen and spores from the Permian and Triassic sediments of the southeastern Iberian ranges, Cueva de Hierro (Cuenca) to Chelva-Manzanera (ValenciaTeruel) region, Spain. Rev. Palaeobot. Palynol. 66:2545.

$\rightarrow$ Durand, M. 2006. The problem of the transition from the Permian to the Triassic series in southeastern France: comparison with other Peritethyan regions. In Lucas, S. G.; Cassinis, G.; and Schneider, J. W., eds. Nonmarine Permian biostratigraphy and biochronology. Geol. Soc. Lond. Spec. Publ. 265:281-296.

- 2008. Permian to Triassic continental successions in southern Provence (France): an overview. Boll. Soc. Geol. Ital. 127:697-716.

$\rightarrow$ Fernández-Suárez, J.; Gutiérrez Alonso, G.; and Jeffries, T. E. 2002. The importance of along-margin terrane transport in northern Gondwana: insights from detri- tal zircon parentage in Neoproterozoic rocks from Iberia and Brittany. Earth Planet. Sci. Lett. 204:75-88.

$\rightarrow$ Fernández-Suárez, J.; Gutiérrez-Alonso, J.; Jenner, G. A.; and Tubrett, M. N. 2000. New ideas on the Proterozoic-Early Palaeozoic evolution of NW Iberia from U$\mathrm{Pb}$ detrital zircon ages. Precambrian Res. 102:185-206.

$\rightarrow$ Frei, D., and Gerdes, A. 2009. Precise and accurate in situ $\mathrm{U}-\mathrm{Pb}$ dating of zircon with high sample throughput by automated LA-SF-ICP-MS. Chem. Geol. 261:261270.

$\rightarrow$ Friedl, G.; Finger, F.; Mcnaughton, N. J.; and Fletcher, I. R. 2000. Deducing the ancestry of terranes: SHRIMP evidence for South America-derived Gondwana fragments in central Europe. Geology 28:1035-1038.

Galán Abellán, A. B.; Fernández Barrenechea, J.; LópezGómez, J.; Benito, M. I.; and Lago San José, M. 2008. Early Triassic-Anisian continental sediments from SE Iberian Ranges: sedimentological and mineralogical features. Macla 9:105-106.

$\rightarrow$ Gerdes, A., and Zeh, A. 2006. Combined U-Pb and Hf isotope LA-(MC)ICP-MS analyses of detrital zircons: comparison with SHRIMP and new constraints for the provenance and age of an Armorican metasediment in Central Germany. Earth Planet. Sci. Lett. 249:4761.

$\rightarrow-$ 2009. Zircon formation versus zircon alteration: new insights from combined U-Pb and Lu-Hf in-situ LA-ICP-MS analyses, and consequences for the interpretation of Archean zircon from the Central Zone of the Limpopo Belt. Chem. Geol. 261:230-243.

$\rightarrow$ Gibling, M. R. 2006. Width and thickness of fluvial channel bodies and valley fills in the geological record: a literature compilation and classification. J. Sediment. Res. 76:731-770.

Hallam, A., and Wignall, P. B. 1999. Mass extinctions and sea-level changes. Earth-Sci. Rev. 48:217-250.

$\rightarrow$ Heydari, E.; Wade, W. J.; and Hassanzadeh, J. 2001. Diagenetic origin of carbon and oxygen isotope compositions of Permian-Triassic boundary strata. Sediment. Geol. 143:191-197

$\rightarrow$ Jackson, S. E.; Pearson, N. J.; Griffin, W. L.; and Belousova, E. A. 2004. The application of laser ablationinductively coupled plasma-mass spectrometry to in situ U-Pb zircon geochronology. Chem. Geol. 211:4769.

$\rightarrow$ Janousek, V.; Gerdes, A.; Vrána, S.; Finger, F.; Erban, V.; Friedl, G.; and Braithwaite, C. J. R. 2006. Low-pressure granulites of the Lišov Massif, Southern Bohemia: Viséan metamorphism of Late Devonian plutonic arc rocks. J. Petrol. 47:705-744.

$\rightarrow$ Kröner, A., and Cordani, U. G. 2003. African, southern Indian and South American cratons were not part of the Rodinia supercontinent: evidence from field relationships and geochronology. Tectonophysics 375 : 325-352.

Linneman, U.; Gerdes, A.; Drost, K.; and Buschmann, B. 2007. The continuum between Cadomian orogenesis and opening of the Rheic Ocean: constraints from LAICP-MS U-Pb zircon dating and analysis of plate-tectonic setting (Saxo-Thuringian zone, northeastern Bo- 
hemian Massif, Germany). In Linnemann, U.; Nance, R. D.; Kraft, P.; and Zulauf, G., eds. The evolution of the Rheic Ocean: from Avalonian-Cadomian active margin to Alleghenian-Variscan collision. Geol. Soc. Am. Spec. Pap. 423:61-96.

$\rightarrow$ Linnemann, U.; McNaughton, N. J.; Romer, R. L.; Gehmlich, M.; Drost, K.; and Tonk, C. 2004. West African provenance for Saxo-Thuringia (Bohemian Massif): did Armorica ever leave pre-Pangean Gondwana? $\mathrm{U} / \mathrm{Pb}$-SHRIMP zircon evidence and the Nd-isotopic record. Int. J. Earth Sci. 93:683-705.

$\rightarrow$ Linnemann, U.; Pereira, F.; Jeffries, T. E.; Drost, K.; and Gerdes, A. 2008. The Cadomian Orogeny and the opening of the Rheic Ocean: the diacrony of geotectonic processes constrained by LA-ICP-MS U-Pb zircon dating (Ossa-Morena and Saxo-Thuringian Zones, Iberian and Bohemian Massifs). Tectonophysics 461: 21-43.

López-Gómez, J., and Arche, A. 1993. Architecture of the Cañizar fluvial sheet sandstones, Early Triassic, Iberian Ranges, eastern Spain. Spec. Publ. Int. Assoc. Sedimentol. 17:363-381.

López-Gómez, J.; Arche, A.; Barrenechea, J. F.; De la Horra, R.; and Galán-Abellán, B. 2011. Permian-Triassic continental rocks of the SE Iberian Ranges: architecture, tectonics and geochemical characteristics in the context of a rift basin. Sociedad Geológica de España, 28th International Association of Sedimentologists Meeting, Zaragoza. Geo-Guias 8:11-43.

López-Gómez, J.; Arche, A.; and Pérez-López, A. 2002. Permian and Triassic. In Gibbons, W., and Moreno, T., eds. The geology of Spain. Geol. Soc. Lond, p. 185212.

López-Gómez, J.; De la Horra, R.; Benito, M. I.; Barrenechea, J. F.; Arche, A.; Luque, F. J.; Alonso Azcárate, J.; Diéguez, C.; and Rodas, M. 2005. Characteristics of Upper Permian continental sediments and their relationship with the End-Permian crisis in the Southern Iberian Ranges, Spain. New Mex. Mus. Nat. Hist. Sci. Bull. 30:172-178.

Ludwig, K. R. 2003. ISOPLOT/Ex, version 3: a geochronological toolkit for Microsoft Excel. Berkeley Geochronology Center Special Publication 4, 71 p.

$\rightarrow$ Martínez Catalán, J. R.; Arenas, R.; Abati, J.; Sánchez Martínez, S.; Díaz García, F.; Fernández Suárez, J.; González Cuadra, P.; et al. 2009. A rootless suture and the loss of the roots of a mountain chain: the Variscan belt of NW Iberia. C. R. Geosci. 341:114-126.

Martínez Catalán, J. R.; Díaz García, F.; Arenas, R.; Abati, J.; Castiñeiras, P.; González Cuadra, P.; Gómez Barreiro, J.; and Rubio Pascual, F. 2002. Thrust and detachment systems in the Órdenes Complex (northwestern Spain): implications for the Variscan-Appalachian geodynamics. In Martínez Catalán, J. R.; Hatcher, R. D., Jr.; Arenas, R.; and Díaz García, F., eds. Variscan-Appalachian dynamics: the building of the Late Paleozoic basement. Geol. Soc. Am. Spec. Pap. 364:163-182.

Martínez Catalán, J. R.; Fernández-Suárez, J.; Jenner, G. A.; Belousova, E.; and Díez Montes, A. 2004. Provenance constraints from detrital zircon $\mathrm{U}-\mathrm{Pb}$ ages in the NW Iberian Massif: implications for Paleozoic plate configuration and Variscan evolution. J. Geol. Soc. 161:461-473.

Marzo, M. 1986. Secuencias fluvio-eólicas en el Buntsandstein del Macizo del Garraf (Provincia de Barcelona). Cuad Geol Iberica 10:207-233.

Murphy, J. B.; Keppie, J. D.; Nance, R. D.; and Dostal, J. 2010. Comparative evolution of the Iapetus and Rheic Oceans: a North America perspective. Gondwana Res. 17:482-499.

Nance, R. D.; Fernández-Suárez, J.; Keppie, J. D.; Storey, C.; and Jeffries, T. E. 2007. Provenance of the Granjeno Schists, Ciudad Victoria, México: detrital zircon U-Pb age constraints and implications for the Paleozoic paleogeography of the Rheic Ocean. In Linnemann, U.; Nance, R. D.; Kraft, P.; and Zulauf, G., eds. The evolution of the Rheic Ocean: from Avalonian-Cadomian active margin to Alleghenian-Variscan collision. Geol. Soc. Am. Spec. Pap. 423:453-464.

$\rightarrow$ Nance, R. D.; Gutiérrez Alonso, G.; Keppie, J. D.; Linnemann, U.; Murphy, J. B.; Quesada, C.; Strachan, R. A.; and Woodcock, N. H. 2010. Evolution of the Rheic Ocean. Gondwana Res. 17:194-222.

$\rightarrow$ Nance, R. D., and Murphy, J. B. 1994. Contrasting basement isotopic signatures and the palinspastic restoration of peripheral orogens: example from the Neoproterozoic Avalonian-Cadomian belt. Geology 22: 617-620.

$\rightarrow$ Sánchez Martínez, S.; Arenas, R.; Díaz García, F.; Martínez Catalán, J. R.; Gómez Barreiro, J.; and Pearce, J. A. 2007. New geochemical data of the Careón Ophiolite: supra-subduction zone setting for the youngest Rheic oceanic floor. Geology 35:53-56.

$\rightarrow$ Schneider, J.; Körner, F.; Roscher, M.; and Kroner, U. 2006. Permian climate development in the northern peri-Tethys area: the Lòdeve basin, French Massif Central, compared in a European and global context. Palaeogeogr. Palaeoclimatol. Palaeoecol. 240:161-183.

$\rightarrow$ Simancas, J. F.; Azor, A.; Martínez-Poyatos, D.; Tahiri, A.; El Haidi, H.; González-Lodeiro, F.; Pérez-Estaún, A.; and Carbonell, R. 2009. Tectonic relationships of Southwest Iberia with the allochthons of Northwest Iberia and the Moroccan Variscides. C. R. Geosci. 341: 103-113.

Sopeña, A.; López-Gómez, J.; Arche, A.; Pérez-Arlucea, M.; Ramos, A.; Virgili, C.; and Hernando, S. 1988. Permian and Triassic rift basins of the Iberian Peninsula. In Manspeizer, W., ed. Triassic-Jurassic rifting: continental breakup and the origin of the Atlantic Ocean and Passive Margins. B. Developments in geotectonics 22. New York, Elsevier, p. 757-784.

Soria, A. R.; Liesa, C. L.; Rodríguez-López, J. P.; Meléndez, N.; de Boer, P. L.; and Meléndez, A. 2011. An Early Triassic evolving erg system (Iberian Chain, NE Spain): palaeoclimate implications. Terra Nova 23:7684.

$\rightarrow$ Stacey, J. S., and Kramers, J. D. 1975. Approximation of terrestrial lead isotope evolution by a two-stage model. Earth Planet. Sci. Lett. 26:207-221.

$\rightarrow$ Stampfli, G. M., and Borel, G. D. 2002. A plate tectonic 
model for the Paleozoic and Mesozoic constrained by dynamic plate boundaries and restored synthetic oceanic isochrons. Earth Planet. Sci. Lett. 196:17-33.

- 2004. The TRASMED transects in space and time: constraints on the paleotectonic evolution of the Mediterranean Domain. In Cavazza, W.; Roure, F.; Spakman, W.; Stampfli, G. M.; and Ziegler, P., eds. The TRANSMED atlas: the Mediterranean Region from crust to mantle. Berlin, Springer, p. 53-80.

$\rightarrow$ Valverde-Vaquero, P., and Dunning, G. R. 2000. New U$\mathrm{Pb}$ ages for Early Ordovician magmatism in Central Spain. J. Geol. Soc. 157:15-26.

$\rightarrow$ Van Wees, J. D.; Arche, A.; Beijdorff, C. G.; López-Gómez, J.; and Cloething, S. 1998. Temporal and spatial variations in tectonic subsidence in the Iberian Basin (E Spain). Tectonophysiscs 300:285-310.

$\rightarrow$ Vargas, H.; Gaspar-Escribano, J.; López-Gómez, J.; Van Wees, J. D.; Cloetingh, S.; De la Horra, R.; and Arche, A. 2009. A comparison of the Iberia and Ebro basins during the Permian and Triassic, eastern Spain: a quantitative subsidence modelling approach. Tectonophysics 474:160-183.

$\rightarrow$ Von Raumer, J. F., and Stampfli, G. M. 2008. The birth of the Rheic Ocean: early Paleozoic subsidence patterns and subsequent tectonic plate scenarios. Tectonophysics 461:9-20.

$\rightarrow$ Von Raumer, J. F.; Stampfli, G. M.; and Bussy, F. 2003. Gondwana-derived microcontinents: the constituents of the Variscan and Alpine collisional orogens. Tectonophysics 365:7-22.

Zhao, G.; Cawood, P. A.; Wilde, S. A.; and Sun, M. 2002. Review of global 2.1-1.8 Ga orogens: implications for a pre-Rodinia supercontinent. Earth-Sci. Rev. 59:125162.

Ziegler, P. A. 1982. Geological atlas of western and central Europe. Amsterdam, Elsevier, 130 p.

1988. Evolution of the Arctic-North Atlantic and the Western Tethys. Am. Assoc. Petrol. Geol. Mem. 43, $198 \mathrm{p}$. 